\title{
TECHNICAL CHANGE AND THE WAGE STRUCTURE \\ DURING THE SECOND INDUSTRIAL REVOLUTION: \\ EVIDENCE FROM THE MERCHANT MARINE, 1865-1912
}

\author{
Aimee Chin \\ Chinhui Juhn \\ Peter Thompson \\ Working Paper 10728 \\ http://www.nber.org/papers/w10728
}

NATIONAL BUREAU OF ECONOMIC RESEARCH

1050 Massachusetts Avenue

Cambridge, MA 02138

August 2004

We thank Josh Angrist, David Autor, Eli Berman, Jon Guryan, Peter Meyer, Peter Mieskowski, and seminar participants at Rice/UH, Cornell, 2004 SOLE meetings, IZA and 2004 NBER Summer Institute Labor Studies Workshop for helpful comments and discussion. The views expressed herein are those of the author(s) and not necessarily those of the National Bureau of Economic Research.

(C2004 by Aimee Chin, Chinhui Juhn, and Peter Thompson. All rights reserved. Short sections of text, not to exceed two paragraphs, may be quoted without explicit permission provided that full credit, including $(\mathcal{C}$ notice, is given to the source. 
Technical Change and the Wage Structure During the Second Industrial Revolution: Evidence from the Merchant Marine, 1865-1912

Aimee Chin, Chinhui Juhn, and Peter Thompson

NBER Working Paper No. 10728

August 2004

JEL No. J23, J31, N31, O30

\begin{abstract}
Using a large, individual-level wage data set, we examine the impact of a major technological innovation - the steam engine - on skill demand and the wage structure in the merchant shipping industry. We find that the technical change created a new demand for skilled workers, the engineers, while destroying demand for workers with skills relevant only to sail. It had a deskilling effect on production work - able-bodied seamen (essentially, artisans) were replaced by unskilled engine room operatives. On the other hand, mates and able-bodied seamen employed on steam earned a premium relative to their counterparts on sail. A wholesale switch from sail to steam would increase the $90 / 10$ wage ratio by $40 \%$, with most of the rise in inequality coming from the creation of the engineer occupation.
\end{abstract}

\author{
Aimee Chin \\ University of Houston \\ Department of Economics \\ 204 McElhinney Hall \\ Houston, TX 77204-5019and NBER \\ achin@uh.edu \\ Chinhui Juhn \\ University of Houston \\ Department of Economics \\ 204 McElhinney Hall \\ Houston, TX 77204-5019 \\ cjuhn@uh.edu \\ Peter Thompson \\ Florida International University \\ Department of Economics \\ Miami, FL 33199 \\ peter.thompson2@fiu.edu
}




\section{Introduction}

Since the 1950s, the returns to high school and the returns to college education in the United States have exhibited rising trends despite an enormous increase in the relative supply of educated workers (Goldin and Katz, 1999, table 7; Autor, Katz and Krueger, 1998, table 1). The only sustained deviation from the trend in returns to college, during the 1970s, is associated with a period of moribund technological advance and an unusually rapid increase in the supply of college graduates. Residual inequality, after controlling for observable characteristics including education, has also shown a notable rise over this period (Goldin and Margo, 1992; Juhn, Murphy and Pierce, 1993; Katz and Autor, 1999). As a consequence, "economic inequality in the United States is higher today than at any time in the past sixty years" (Goldin and Katz, 1999, p. 1).

It is widely accepted that skill-biased technological change underlies this evolution of the wage structure. Skilled and educated workers may be better at using (Griliches, 1969; Jovanovic, 1998; Caselli, 1999) or learning (Nelson and Phelps, 1966; Greenwood and Yorukoglu, 1997; Rubenstein and Tsiddon, 1999; Galor and Moav, 2000) new technologies, so in periods of rapid technological change the demand for skill can outstrip even a rising supply. At the same time, a rising supply of skilled workers may induce technical change biased to such an extent that the skill premium rises (Acemoglu, 1998, 2002).

Although wage inequality declined prior to the 1950s, and especially during the 1940 s, technical change still appears to have been skill-biased. Goldin and Katz (1998) associate interindustry variations in wages and employment of educated workers between 1909 and 1929 with the use of continuous-process and batch methods of manufacturing, and the adoption of electric motors. They conclude that wage inequality was prevented from rising only by the massive increase in education brought about by the high school movement after 1910 . 
While there has long been a consensus that technological change in the nineteenth century was deskilling (e.g., Braverman, 1974; Marglin, 1974), the evidence turns out to be sparse. Perhaps best known is James and Skinner's (1985) examination of the substitution of capital for skilled and unskilled labor at mid-century, which suggests that technological change was skill-saving. But recent evidence from changes in earnings inequality around this period (Meyer, 2002) is by contrast consistent with a process of skill-biased technological change. The reality is likely to be more complex. The reorganization of the factory associated with the development of interchangeable parts in numerous industries during the latter half of the nineteenth century facilitated the substitution of unskilled factory workers for skilled artisans (Hounshell, 1984; Mokyr, 1990), but at the same time it created a new demand for, inter alia, engineers, managers and clerks (Goldin and Katz, 1998).

Our understanding of the impact of technological change on the wage structure during the nineteenth century is undoubtedly constrained by an almost complete absence of individual-level wage data, without which we cannot begin to address many questions that have been the focus of attention in studies of more recent periods. We do not know the extent to which new demand for skills in scarce supply or declining demand for skills in abundant supply may have shaped the wage structure. We do not know whether new technologies induced a premium for high quality workers that were able to learn new skills or to function in an uncertain environment. It is consequently no surprise that we are also not in a position to assess whether changes in the wage structure are permanent, or whether they can be explained by a microeconomic Kuznets effect (Rogers, 1995) whereby transitory increases in wage inequality arise because at any point in time only a fraction of firms have adopted the new technology.

In this study we exploit individual-level wage data from the merchant marine to shed light on how technological innovation affected the demand for skills and consequently the wage 
structure in the latter half of the nineteenth century. The specific technological innovation we examine is the development of steam propulsion and its substitution for sail. Our data consist of individual-level wage observations for a large sample of workers serving on vessels registered in the Atlantic provinces of Canada from 1865 to 1912, a period spanning the wholesale substitution of steam for sail. ${ }^{1}$ The wage data are not only numerous, but also high quality-they are derived from crew lists which served contemporaneously as binding employment contracts. ${ }^{2}$ In addition to providing precise wage data, the crew lists also record each individual's age, nationality, literacy, and job classification, as well as descriptions of the voyage undertaken. Furthermore, the individuals' data are linked to vessel registry records containing key technological details of the ships, including its age, size, and form of propulsion. In sum, our data is the earliest example of matched employer-employee data that we are aware of, containing detailed characteristics of both the worker and the firm.

Despite their antiquity, the data have several clear advantages over those previously used to examine the effect of technological innovation on skill demand. First, most of the recent studies linking computer-related technology to skill demand have utilized inter-industry variations and have used investment in computers to proxy for technical change (Berman, Bound and Griliches, 1994; Autor, Katz, and Krueger, 1998). Studies that have used more detailed plant-level data have nevertheless relied on indirect measures of technical change such as the adoption of various factory automation technologies (Doms, Dunne, and Troske, 1997). In contrast, our data allow a precise and unambiguous link between the worker, the firm, and the

\footnotetext{
${ }^{1}$ Although all the individuals in the sample serve on vessels registered in Canadian ports, they are not necessarily Canadian. Merchant vessels picked up workers at their various ports of call, and Canadian merchant vessels can be thought to be drawing from the same labor supply as merchant vessels registered in other countries. Over fifty nationalities are represented in the sample.

${ }^{2}$ Most notably, a failure on the part of the employee to fulfill the terms of his contract was a criminal offense. The crew list also protected the employee by laying out the responsibilities of the employer. However, most failures by the employer to meet his obligations constituted a civil offense.
} 
old and new technology. What constitutes a firm in our data also leaves less concern about endogenous adoption - the idea that the better firms hire more skilled workers and are also the first to adopt more advanced technologies. The firm in our data is not an on-going concern but is the vessel on a particular voyage. The firm changes with the hiring of the crew and it is clear that the technology dictates the skill composition of the crew rather than the reverse. ${ }^{3}$

To preview the results, we find considerably greater wage inequality on steam-powered vessels than on sail vessels. Differences in occupational composition explain most of the higher inequality. The wage bill share of able-bodied seamen and ordinary seamen was $65 \%$ on sailpowered ships while it was less than $20 \%$ on steam-powered ships. These moderately skilled production workers were replaced on steam vessels in part by highly skilled and highly paid engineers and in part by unskilled engine room operatives, who together accounted for over 50\% of the wage bill share. Thus, the new technology was not simply skill-biased or deskilling. While the switch from sail to steam replaced semi-skilled production workers with less skilled production workers on the one hand, it also created the need for a new class of skilled workers who were responsible for the maintenance of the machines. Our findings are therefore similar to Goldin and Katz's (1998) description of the movement from skilled artisans to the factory during the earlier part of the nineteenth century.

We also find substantial within-occupation steam premia. Most strikingly, able-bodied seamen serving on steam vessels earn one-fifth more than their counterparts on sail vessels, even after controlling for a variety of individual, voyage, and vessel-level characteristics. Our data are rich enough to allow us to eliminate compensating differentials as a candidate explanation for this premium. This premium is likely related to skill. Since fewer able-bodied seamen were hired

\footnotetext{
${ }^{3}$ Of course, the adoption of steam technology at a more aggregate level may be driven in part by the available skill supply (Acemoglu, 1998).
} 
on steam, each individual had to be capable of performing a larger set of tasks and it is likely that those that were hired had to be of higher average ability.

Our paper also sheds light on the evolution of the skill premium between 1865 and 1905. Of course, our findings are for one particularly industry but we think the unusual detail and quality of our wage data make exploration worthwhile. To study the skill premium over this longer period, we restrict our analysis to sail since the number of steam observations is sparse in the earlier part of our data. We find that skilled workers earned about twice as much as unskilled workers. Wage inequality among workers on sail vessels shows no particular trend over the sample period, suggesting that the crude wage structure there was largely unaffected by the gradual switch to a new technology. However, the crude wage structure hides distinctive wage patterns across occupations that were differentially impacted by the diffusion of steam. Wages fell in occupations which utilized skills not readily portable to steam, such as the sail makers and able-bodied seamen.

\section{Background}

Thomas Newcomen invented the first steam engine to see commercial success in 1712, but its mass and inefficiency restricted its use to pumping water out of mines. James Watt's improved design, first patented in 1769 and soon after made commercially available through Watt's enormously successful partnership with Matthew Boulton, made the steam engine sufficiently compact and fuel efficient to open the door to a wider set of applications. Indeed the steam engine has been characterized as a General Purpose Technology (Rosenberg and Trajtenberg, 2001; Crafts, 2004). The steam engine enabled the conversion of heat energy to mechanical energy, and so any industry that needed portable power might find the steam engine useful. For example, it could power factories, power railroads and propel ships. In this paper we focus on the application of the steam engine to transoceanic transport. 
The potential benefits of steam power to water transportation were tremendous. With steam propulsion, a vessel was able to make progress in its journey even when the wind and current were unfavorable. This meant that time to destination was shorter on average and also less variable; unfavorable wind and current could keep a sail vessel idling at sea for days or weeks. It also allowed steamship companies to publish scheduled routes and promise delivery times. Steam was quickly adopted for river, lake and coastal transport. However, it took a long time before steam became the preferred technology for transoceanic transport. This was because early steam engines required too much fuel for long voyages and thus could not compete with sail. The first steam-powered vessel to cross the Atlantic, the SS Savannah, did so in 1818, but steam was just an auxiliary source of power and the vessel spent 26 of its 29 days at sea under sail (see Figure 1). Three British companies had vessels cross the Atlantic entirely under the power of steam in 1838 , but fuel consumption remained a problem. One vessel arrived in port only after burning its cabin furniture, a spare mast and half its decking; none of the three companies were successful financially. ${ }^{4}$ Even in the mid-nineteenth century, daily coal consumption of ocean-going steam vessels was around one hundred tons, meaning much valuable cargo space was usurped for coal storage.

In fact, it was not until the mid-1880s, after numerous engineering improvements had been made to the steam engine and the building of steamships, that steam became more attractive than sail for transoceanic transport. ${ }^{5}$ Ship owner W.B. Forwood wrote in 1891: "[T]he steamer of today can travel five times as far upon the same coal consumption as the steamer of 40 years

\footnotetext{
${ }^{4}$ Two companies abandoned the Atlantic in 1840. The third company, the owner of the famous Great Western, closed down in 1846 .

${ }^{5}$ Some key improvements included screw propulsion, steel hulls and boilers, and triple expansion engines. See Gardiner and Greenhill (1993).
} 
ago." ${ }^{6}$ The world tonnage of sail-powered merchant vessels reached a maximum in 1880, even as world tonnage of merchant vessels grew (Gardiner and Greenhill, 1993, table 1). After the mid-1880s, merchant shipping companies were phasing out sail vessels and adding steam vessels to their fleets. In 1860 , only $12 \%$ of the world merchant tonnage was steam (some would be for inland waterway and coastal trade); the steam share had increased to $46 \%$ by 1890 and $76 \%$ by 1910.

Britain led the way in developing a transoceanic steam fleet, aided by the early adoption of steam by the Royal Navy (in 1820), government subsidies granted under the guise of mail contracts (from 1830), and the establishment of an extensive network of military coal depots throughout the empire (from 1840). In 1910, 90\% of the United Kingdom's merchant tonnage was steam. The switch to steam power for transoceanic transport was slower in North America. Figure 2 shows that despite the later start, steam inevitably came to dominate the Atlantic Canadian ocean-going fleet. ${ }^{7}$ In just a twenty-year span, steam-powered vessels took over transoceanic transport: they accounted for only $11 \%$ of all ocean-going vessels in 1890 , but $67 \%$ by 1910 .

\section{Data}

We use data on vessels and crew members compiled by the Atlantic Canada Shipping Project at Memorial University at Newfoundland in the late 1970s and published in electronic form by the Maritime History Archive in 1998. These data have been studied extensively by maritime historians (e.g. Sager, 1989, 1993; Sager and Panting, 1990), but they have yet to be brought to the attention of economists and analysis has so far been restricted to tabulations of

\footnotetext{
${ }^{6}$ Quoted in Tyler (1939, p. 371).

${ }^{7}$ The data on which Figure 2 is based are described in the next section.
} 
sample means. ${ }^{8}$

Information on vessels, including their type, dimensions and age, are in the vessel registry database. This database covers the universe of vessels listed in the shipping registries of ten major Atlantic Canadian ports from 1787 to $1936 .{ }^{9}$ For a subset of the vessels, researchers also compiled information from crew agreements. A crew agreement contains information on each crew member's name, date of birth, ${ }^{10}$ place of birth, wages, rank, place of joining and leaving the vessel and so forth. Researchers recorded individual-level data from the crew agreements for about $30 \%$ of the vessels registered in four ports (Saint John, New Brunswick, Yarmouth and Halifax). For all the vessels registered in these four ports, they recorded data on the voyages taken, including intended destination, intended duration and start date.

We define a vessel's technology based on the "type of vessel" variable. Researchers placed each vessel into one of seventeen categories: steamer; steam/sail; steam/paddle; schooner; brig; brigantine; barque; barquentine; ship; sloop; ketch; cutter; shallop; snow; other; fuel only (oil, gas or kerosene without sails); and fuel with sails. We classify members of the first three categories as steam-powered vessels. The steam/sail category contains vessels that have steam propulsion, but also use wind as an auxiliary power source. We classify the following five categories as ocean-going vessels: steam/sail; barquentine; barque; brig; and ship.

We matched the individual-level data from the crew agreements to the vessel-level data (using the official vessel number available in both databases); this enables us to identify the

\footnotetext{
${ }^{8}$ One exception is Thompson (2003), who used the data to test theories of technology diffusion.

${ }^{9}$ Ship owners of the British Empire were required by law to register their vessels with the customs officer in their home port, and so the database should accurately reflect ships with home ports in Atlantic Canada.

${ }^{10}$ Although no data are available to confirm it, we think that age serves as a good proxy for marine experience. Sager (1993, p. 37) points out that "Most went to sea when they were young. This was true of workers in Canadian sail ships in the nineteenth century, and it was true in the twentieth century as well. It was rare for an older person, with a good job on land, to join the company of seafarers, unless wartime service required it."
} 
technology on which each worker worked. A vessel makes multiple voyages over its lifetime, and we matched the individual-level data to voyage-level data as well in order to control for certain voyage characteristics; the voyage is probably the unit most comparable to a firm. We restrict the sample to international voyages; the domestic coastal trade may have faced different labor market constraints. ${ }^{11}$ We have therefore eliminated individuals on voyages with Canada as both the country of embarkation and country of intended destination, or on voyages less than six months in intended duration, or on small vessels not intended for ocean-going trade. Furthermore, to make the measured wages more comparable, we only include workers paid on a monthly basis in British sterling, U.S. dollars or Canadian dollars. In practice, few workers were paid at a different frequency or in a different currency. Using exchange rates from Officer (2001), we have converted all monthly wages to British sterling. These wages are then converted to 1900 prices using the British consumer price index from McCusker (2002). We are left with approximately 149,000 individual-level observations for the time period spanning 1861 to 1912 . However, because there are numerous individual observations with missing wage data in the first few years, we restrict our analysis to the period 1865-1912.

Of the 149,000 observations, only 4,000 are for individuals working on steam vessels. Although steam was spreading over the entire period, it did not become dominant until the twentieth century, and by this time the Atlantic Canadian fleet was rather smaller than it had been earlier. But this explains only part of the relatively small sample size for steam: researchers also compiled more individual-level data for the earlier period than the later period. Given this, our empirical analysis on technical change and the skill premium will be based on sail and steam observations from 1891 to 1912 . During these last two decades of the sample period, we have

\footnotetext{
${ }^{11}$ Some of the domestic voyages pertained to the fishing and whaling industries. Also, employer-employee relationships on domestic voyages were generally more personal than on international voyages (Sager, 1989).
} 
observations on both technologies. Thus, sample moments for both technologies would reflect the common macroeconomic conditions. Our empirical analysis concerning the evolution of the skill premium will be based on sail observations only since we want consistent data spanning as long a period as possible.

Figure 3 shows that in most years steam-powered ships are under-represented in the individual wage data, which raises concerns about whether this sample is representative of all workers serving on ocean-going vessels. Only beginning in 1907 does the fraction of vessels that are steam-powered in the sample approximate the fraction in the population. This means that for the years before 1907, the sample moments will be too heavily weighted by sail. But even though we cannot get the correct sample moments for transoceanic transport as a whole, the data still provide insights about steam and sail separately. In particular, we argue that the steam observations in the sample are representative of all workers serving on steam-powered vessels, and similarly that the sail observations are representative of all workers serving on sail vessels. To advance this argument, we first compare the vessels for which we have individual-level crew information ("in sample") to the vessels that are not in the sample. Recognizing that the "steam/sail" category of ocean-going vessels is rather heterogeneous, we focus on international voyages made by the vessels. We compare the voyages that are in our sample to voyages that are not in our sample.

Table 1 shows that from 1891 to 1912, approximately $27 \%$ of all registered ocean-going vessels in the four ports are in our sample. The center two columns show that the age and dimensions of the sail vessels that are in the sample do not differ much from those that are not, which bolsters the case that our sail observations may be representative. The right-most two columns show that the steam vessels in the sample are physically much larger than those not in the sample. This appears to be an artifact of how vessels are categorized. As noted before, all 
vessels were placed in one of seventeen categories, only three of which were steam. The more detailed categorization of sail vessels enabled us to eliminate types of sail vessels not intended for crossing oceans. We are not able to do this equally well for steam vessels. We have eliminated steamers and steamboats with paddles from the sample, as these were typically used for short-distance transport. But the remaining steam category, "steam/sail" is broad. Judging from the low average tonnage of the 148 steam vessels that are not in the sample, it seems that many short-distance vessels have been placed into the steam/sail category.

Although our steam observations cannot be considered representative of all workers in steam vessels, nonetheless they might be considered representative of all workers in steam vessels capable of making international voyages. In Table 2, we present the characteristics of international voyages taken by ships in the sample to those not in the sample. The right-most two columns show that our steam observations reflect all the international voyages taken by steam vessels between 1891 and 1912 . The sail observations capture $42 \%$ of all the international voyages taken by sail vessels, and since the characteristics of the ships and voyages do not differ much, we shall assume them to be them representative of all workers in sail vessels capable of making international voyages.

\section{Results}

Much previous analysis of the effects of technological change on the wage structure has been limited to the question of whether change is skill-biased or deskilling. This is perhaps too crude a question. Sail and steam vessels provided substitutable shipping services, but they did so using very different production technologies and the substitution of steam for sail consequently affected the demand for labor in a number of distinct ways. First, it reduced the demand for occupations specific to sail, and we would expect to observe a decline in the wages of workers with these technology-specific skills. Second, it created a demand for new occupations, only 
some of which required new skills. We would anticipate a premium to be paid for workers with the appropriate skills if they are initially in scarce supply (cf. Chari and Hopenhayn, 1991). Finally, the advent of steam changed the character of many occupations that survived the transition from sail to steam. In some occupations common to both technologies, the demand for skill or, perhaps more accurately, quality may have declined, while in others it may have risen. In only a fraction of occupations common to both technologies should we expect no substantive change in the character of the job.

Table 3 shows how the occupational composition of the crew differed between steam and sail vessels in terms of raw numbers and employment share. The table reports averages for 1891 to 1912. While total crew size was similar on steam (35) and sail (32), there were striking differences in the composition of the crew. The shift to steam made some jobs, such as the sail maker, obsolete. It also changed the mix of workers across occupations common to both technologies. The sail crew typically had 23 able-bodied seamen, a steam crew had only nine. The employment share of able-bodied and ordinary seamen fell from 77 percent on sail ships to 27 percent on steam ships.

Most of the decline in the employment share of seamen is offset by the addition of workers in the new engine room. The steam crew had an average of 16 workers in the engine room, four engineers and twelve engine room operatives. These new occupations accounted for over $46 \%$ of the total employment on steam vessels. The skilled workers were the engineers, who "were required to tend the machinery, ensure that it was operating properly, undertake repairs, start, stop and reverse the engines when arriving or leaving port, and supervise the firing of the boilers" (Griffiths, 1997, p.132). Pursuant to an 1862 amendment to the Merchant Shipping Act, seagoing engineers were required to obtain a certificate of competency (an examination and sufficient training were required), and all steam-powered vessels had to have 
certified engineers aboard. The production workers in the engine room were the firemen, trimmers, donkey men, and oilers and greasers, who provided mostly manual labor under the management of the engineers. The most numerous of these engine room operatives were the trimmers, who carried coal from the storage areas to the boiler areas, and the firemen, who shoveled coal into the boilers to generate steam. Both the skilled (engineers) and unskilled (engine room operatives) spent their work time in the engine room, isolated from the rest of the crew.

Many occupations on sail vessels carried over to steam vessels as well. The master was the person in charge of the voyage, assisted by one or more mates. The mates transmitted the master's orders to the seamen, commanded a share of the seven round-the-clock watches each day, had responsibility for the cargo, kept the log-book detailing the journey, and made navigational measurements. The mates were capable of performing the physical tasks any ablebodied seamen was, although they rarely had to do them. The majority of the masters and mates had attained their high status only after passing examinations administered by the government. The mariners - in order of experience, they were the able-bodied seamen, ordinary seamen and boys/apprentices - were the most numerous production workers on vessels. They were expected to undertake a wide variety of tasks under the direction of the mates. ${ }^{12}$ This included handling the sails, steering, standing watch, maintaining the appearance and structural integrity of ship, and handling lines for docking and departing.

However, even among ranks that survived the transition from sail to steam, the nature of the skills involved often changed markedly. On sail vessels, as one mariner recalled, "three

\footnotetext{
${ }^{12}$ The sample records over 60 distinct job titles that are not discussed here. Most of them were absent from a typical voyage.
} 
quarters of [one's] waking time is devoted to fondling rope"13 and there were many ropes to learn (see Figure 4). Locating and handling the rigging was a skill arduously learned before promotion from ordinary to able-bodied seaman. These skills did not completely lose their value on steam vessels, as even at the close of the nineteenth century steam vessels continued to be equipped with sails. ${ }^{14}$ However, steam vessels likely valued a different set of qualities in their able-bodied seamen compared to sail vessels. The mariner on a steam ship "had become a tender of new types of machinery, and ship-owners were prepared to pay a premium to hire experienced and reliable men" (Sager, 1989, p. 261). Yet a further challenge to the production workers on steamships was a change in workplace composition. Not counting the engine room, the number of mariners on a steamship was typically less than half the number on a sail vessel of similar size, possibly increasing the range of responsibilities and tasks performed above deck for any single mariner.

These changes in occupational composition, in conjunction with changes in skill requirements within occupations, can be expected to change the wage structure in the maritime industry. However, evaluating how these changes in labor demand might affect the wage structure is complicated by the fact that working conditions varied both across technologies and across occupations within technologies, so that changes in the wage structure reflect at least in part required compensating differentials.

We can avoid the confounding of skill premia with compensating differentials if, in the first instance, we restrict attention to changes in the wage structure on sail vessels alone. This we do in the subsection A, where we are able to trace the evolution of the skill premium over an

\footnotetext{
${ }^{13}$ Quoted in Sager (1989, p. 133).

${ }^{14}$ The sails might be stored during a voyage, and the sail plan tended to be less complicated than that for sail vessels. See Gardiner and Greenhill, 1993, Chapter 8.
} 
extended period of dramatic technological change. We restrict attention to the period 1865 to 1905 because relatively few observations for sail are available after 1905. Of course, looking at sail alone provides only a partial picture, so in subsections B, C and D, we analyze differences in wages across the two technologies. However, the unusual detail of our data allows us to make progress in discriminating between skill premia and compensating differentials. The crosstechnology comparisons focus on the period 1891 to 1912, the period during which we have sufficient observations on steam.

\section{$\underline{\text { A. Wage inequality and the skill premium on sail vessels, } 1865-1905}$}

Relatively little is known about skill premia and the wage structure during the latter half of the nineteenth century. Atack, Bateman and Margo (2000) report that wage dispersion across manufacturing establishments rose in the U.S. during this period. Meyer (2002) shows that within-industry wage inequality increased, particularly in industries experiencing rapid technical change. However, skill premia measured by occupational wage ratios exhibit relatively little movement over this period (Lindert and Williamson, 1980). In Britain, the evidence suggests that skill premia fell at the end of the nineteenth century (Williamson, 1980; Lindert and Williamson, 1983).

Our purpose in this section is two-fold. First, we bring more data to the continuing debate regarding the evolution of the skill premium. While our study covers one industry-the transoceanic shipping industry — the quality and detail of our data is quite unique. With our data, we can examine overall inequality such as the $90 / 10$ wage ratio as well as skill premia measured as occupational pay ratios or the literacy premium. Our second purpose is to understand how the introduction and diffusion of new technology affected the wage structure over time. The previous section suggests that steam had differential impacts on demand across job categories. It diminished the need for able-bodied seamen and made some occupations, such as sail making, 
completely obsolete. On the opposite end of the spectrum, the demand for workers in other occupations, such as mates and cooks were relatively unaffected. We examine whether there were different changes in wages across occupations depending on the portability of skills across technologies.

In Figure 5 , Panel $\mathrm{A}$, we plot the $90^{\text {th }}, 50^{\text {th }}$ and $10^{\text {th }}$ percentile wages and mean wages by year for men aged 16 to 65 working in sail vessels. During the four-decade span, the relative wages of the higher-paid to lower-paid did not change dramatically. The $90^{\text {th }}$ percentile wage is on average 2.2 times the $10^{\text {th }}$ percentile wage and 1.7 times the median wage. The median wage is 1.3 times the $10^{\text {th }}$ percentile wage. The mean is higher than the median, and the median is much closer to the $10^{\text {th }}$ percentile wage than the $90^{\text {th }}$ percentile wage, indicating that most of the workers are concentrated at the bottom of the wage distribution. This is not surprising since the bulk of the crew are ordinary seamen and able-bodied seamen, who account for both the $10^{\text {th }}$ and $50^{\text {th }}$ percentile workers. Their wages are more similar to each other than to the mates who are the $90^{\text {th }}$ percentile workers.

The ratio of the $90^{\text {th }}$ percentile wage to the $10^{\text {th }}$ percentile wage, a standard measure of wage inequality, ranges from 1.8 to 2.7 over the four-decade period, as shown in Figure 5, Panel B. The $90 / 10$ ratio for this period is lower than what has been observed for much of the twentieth century. Goldin and Margo (1992) calculate the ratio at each decennial year since 1940, the first U.S. Census for which earnings micro data are available, and find that the lowest value was 2.9 in 1950 . The $90 / 10$ ratio we have calculated for the end of the nineteenth century is lower because we are examining only one industry, whereas studies using more recent micro data use all industries. The maritime industry, and likely other industries impacted by the steam engine such as manufacturing and land transportation, was neither the highest-paying nor the lowestpaying industry. 
As a direct proxy for skill, in Figure 6 we plot wages by literacy and year. An individual is coded as literate if he signs his name on the crew agreement, and illiterate if he put down an "X" ${ }^{15}$ Panel A shows that mean wages were higher for the literate; literate seamen were paid an average ten percent more than illiterate seamen. Panel B shows that the $10^{\text {th }}$ percentile wage is the same for both the literate and illiterate, but the $90^{\text {th }}$ percentile is higher for the literate. In other words, wage inequality is higher for the literate. The ratio of the $90^{\text {th }}$ percentile wage to the $10^{\text {th }}$ percentile wage is 2.4 for the literate, 1.9 for the illiterate. There is no change over time in the premium for this measurable component of skill

We might also measure skill using occupation. The wage inequality literature often looks at the wage differential between non-production and production workers, or white-collar and blue-collar workers, to describe the skill premium. We take mates to be the skilled/nonproduction/white-collar workers and the able-bodied seamen to be the less skilled/ production/blue-collar workers. The mates are able-bodied seamen who have passed the necessary examination to be certified and subsequently managed to find a job as mate. Mates spend most of their time engaged in managerial and supervisory activities, and record-keeping. The second mate and third mate might still perform physical tasks alongside the able-bodied seamen, but the first mate would not. We plot the wages for mates and able-bodied seamen in Figure 7. Panel A shows that, as expected, mean wages are higher for mates than for able-bodied seamen. Mates' wages are on average 1.9 times able-bodied seamen's wages, with a range over time from 1.6 to 2.3 . In contrast to the stability of the $90-10$ wage ratios we reported earlier, the ratio of wages of mates and able-bodied seamen shows an upward trend (Panel B). This is not surprising given the sharp reduction in demand for able-bodied seamen in steam-powered vessels

\footnotetext{
${ }^{15}$ This level of literacy is more likely to be a proxy for numeracy, a more valuable skill for most crew members.
} 
shown in Table 3 and given the rapid adoption of steam technology even among ocean-going vessels at the end of the nineteenth century.

While we have little information about supply, we know that demand for certain occupations and skills declined with the introduction of steam technology. Figure 8 shows the evolution of wages in three occupations distinguished by the portability of skills across technologies. We indexed wages to the average value over 1865-1867, the beginning period of our sample. Average wages of cooks, an occupation that was essentially unaffected by the switch in technology, was about the same in 1905 as it was in 1865. In sharp contrast, the average wage of sail makers, an occupation that had become all but obsolete with the introduction of new technology, fell approximately 20 percent. We have not graphed years with fewer than 25 observations, but if we included these years, the decline in sail maker wages would be even larger. Average wages for able-bodied seamen also fell, although the precise amount depends on how much weight we place on the last few observations where the number of wage observations in sail becomes relatively sparse.

To put our findings in context we compare in Figure 9 the ratios of wages of mates to able-bodied seamen to other skill premia reported elsewhere. In Panel A we juxtapose the mates/able-bodied seamen wage ratio from our data (line marked by squares) to skill ratios in British printing and building trades as reported in Williamson (1980). The figure also includes skill ratios from the U.S. over the same time period reported in Lindert and Williamson (1980). Panel B compares our occupational premium to other white-collar/blue-collar wage ratios, such as the wage ratio of clerks to unskilled labor in Britain, as well as the wage ratios of ministers to unskilled labor in Britain and U.S. The figure illustrates that the mate/seamen premium we report is more in line with skill ratios measured within manufacturing or other blue collar occupations. The white-collar premium was orders of magnitude larger. However, consistent with what we 
find in our data, skill premia did not change remarkably during 1865-1905, particularly in the U.S. ${ }^{16}$ There is some evidence that the white-collar premium fell at the turn of the century in Britain. $^{17}$

This subsection has provided new empirical evidence on the wage structure for the period 1865 to 1905 . The skilled worker on sail vessels (defined either as the $90^{\text {th }}$ percentile wage earner or the non-production worker) made approximately twice as much as the unskilled worker (defined as the $10^{\text {th }}$ percentile wage earner or the production workers). The skill premium was fairly stable over the four decade period, despite the steady substitution of steam for sail. We find that wages in occupations which became obsolete with the diffusion of steam technology steadily declined over the period.

\section{B. Technology, wages, and the demand for new skills, 1891-1912}

Because steam vessels are underrepresented in our sample, it is not useful to construct estimates of industry-level wage inequality from our individual wage observations. Instead, Figure 10 plots mean wages (panel A) and the $90^{\text {th }}$ and $10^{\text {th }}$ percentile wages (panel B) separately for workers on sail and on steam for the period 1891 to 1912. Mean wages were higher in steam than in sail, as shown in Panel A. On average, workers in steam vessels were paid 1.43 times workers in sail vessels. Panel B shows that the $90^{\text {th }}$ percentile wage is higher in steam, but the $10^{\text {th }}$ percentile wage is similar between steam and sail. Consequently, wage inequality was greater in steam than in sail. Over this period, the average 90/10 ratio was 2.1 in sail and 2.9 in steam. At the aggregate level, we would therefore expect to observe a significant rise in

\footnotetext{
16 Atack, Bateman and Margo (2000) do find, however, that wage inequality between establishments rose in American manufacturing during 1850 to 1880 .

17 The ratios we report are also similar to wage ratios of skilled to unskilled workers calculated for the early twentieth century (see Goldin and Margo, 1992, Table VII). One series from Goldin and Margo seems especially comparable to ours - the ratio of monthly wages of clerks to laborers in class-I steam railroads. This series begins in 1922 at 1.57 , is stable through the 1920s, rises to as much as 2 in the 1930 s, and then declines through the 1930 s and 1940 s.
} 
inequality as steam gradually displaced sail. These crude numbers suggest that technical change in the maritime industry during this period was skill-biased.

Probing further, Table 4 reports the average wages for the major occupations on steam and sail. The most notable feature is the high wages paid to engineers and engine room operatives. Engineers were highly paid in large part to reward skills earned after only extensive training, and for which remunerative opportunities also existed on land. In fact, as Table 4 shows, engineers were on average the highest paid members of the crew ${ }^{18}$, sufficiently so that when they are eliminated from the sample much of the cross-technology difference in wage inequality is eliminated. As Figure 11 shows, steam workers still have higher mean wages after excluding engineers from the sample, but the difference is smaller (the steam premium is 26 percent instead of 43 percent). Naturally, the $10^{\text {th }}$ percentile wage continues to be similar between steam and sail, but the elimination of engineers reduces the average 90/10 ratio from 2.94 to 2.35 . Thus, creation of just the engineer occupation accounts for almost half the average steam-premium, and most of the greater wage inequality in steam.

The engine room operatives were also paid well, but we know that their jobs involved markedly less skill than was expected of, say, able-bodied seamen. The higher wages for engine room operatives undoubtedly reflect a compensating differential for the unpleasant work environment in the engine room. "Keeping a steamer's boiler fired was hard, hot and dirty work" (Griffiths, 1997, p. 133) that produced unusually unhappy workers. Sager (1993, p. 44) reports that in the British merchant marine 100 firemen and trimmers committed suicide in 1893 and 1894: "Driven mad by the heat, they would throw themselves overboard."

The environment for engineers was little better. "[K]eeping the boilers and engines in an

\footnotetext{
${ }^{18}$ Wages for masters are not in the data set. The master has his own contract with the ship owner, and would not appear in the crew agreements.
} 
efficient operating state was equally demanding. Work was hot and often dangerous, many engineers suffering injury through coming into contact with operating machinery or being scalded while repairing some part of the steam plant" Griffiths (1997, p. 133). We must, therefore, conclude that some significant part of the high wage for engineers is likely to represent a compensating differential rather than a skill premium.

\section{Within-occupation steam premia}

Table 4 also documents a substantial wage premium associated with steam within some occupations that survive the transition. Mates earned 25 percent more on steam than did their counterparts on sail; able-bodied seamen on steam earned 21 percent more while ordinary seaman earned 15 percent more. At the same time, however, bosuns and cooks, earned less on steam. These within-occupation differences may be due either to variations in worker quality or to the presence of a compensating differential.

In this subsection we investigate possible sources of these wages differences using a regression framework. In the first place, we test whether observable skills explain the crosstechnology wage differences by adding as independent variables age (which might proxy experience), literacy (which might proxy numeracy) and country of birth (which might proxy education or exposure to the steam technology). In the second place, we test whether compensating differentials explain the wages differences by adding as independent variables characteristics of the voyages and vessels that might make the work environment more or less pleasant (length and destination of voyage, age and tonnage of the vessel). We then attribute any remaining technology wage differentials to unobserved differences in worker quality.

Table 5 reports cross-technology regression-adjusted differences in mean wages in each of the principal occupations common to both technologies. Column 1 controls for a quadratic in 
worker age and year dummies. ${ }^{19}$ This makes the steam premium fall significantly for ordinary seamen and mates. The previously-observed steam premium for ordinary seamen is entirely eliminated, and that for mates is halved. In contrast, the addition of age and year controls has little impact on the measured steam premium for able-bodied seamen, bosuns and cooks and stewards. Finally, their addition makes the steam premium for carpenters become positive and significant.

Next, we add a direct measure of skill — whether the worker can sign his own name—as a control variable. In our sample from 1891 to $1912,15 \%$ of the seamen were illiterate, although literacy was rising steadily over the entire period. But it turns out that controlling for literacy does not affect our estimates of the skill premium, as can be seen in the column 2 of Table 5 . Perhaps literacy is sufficiently common that it was not difficult to hire a literate worker. The illiterate workers that are hired might be exceptional in a skill dimension that is valued by the employer, but not correlated with literacy.

Another potential proxy for skill is country of birth. Depending on where the worker grew up, his quantity and quality of schooling, training and work experience could be quite different. Wages could therefore be expected to differ. In column 3, we control for a full set of country of birth dummies. The steam premium for mates is cut in half, but that for other occupations remains the same magnitude as in the basic specification. This appears to arise from the fact that steam vessels are more likely to hire British mates. ${ }^{20}$ The British merchant marine

\footnotetext{
${ }^{19}$ Only a small fraction of the difference between the raw steam premium in Table 4 and the adjusted steam premium in Table 5, Column 1 is due to the addition of the age controls. The bulk is due to the addition of year dummies. While the age controls might measure skill (mariner experience), the year controls do not. Especially in occupations where number of observations is small, and macroeconomic conditions are changing leading up to World War I, it is perhaps not surprising that adjusting for year of embarkation makes such a difference. We are looking only at within-year cross-technology wage differences.

${ }^{20}$ In our sample, $40 \%$ of mates on steam vessels are British, compared to only $23 \%$ in sail vessels. In contrast, the proportion of able-bodied seamen who are British is similar between the two technologies $(21.1 \%$ for sail and $21.6 \%$ for steam).
} 
was the earliest adopter of the steam engine, the most widespread user of formal apprenticeships, and the pioneer in professionalizing the service (Burton, 1990), and so the tendency to hire British mates on steam can likely be interpreted as related to skill.

In column 4, we attempt to partial out the cross-technology wage differences due to compensating differentials. Compensating differentials would account for the steam premium if the work environment was less pleasant on steam vessels. This is obviously true in the engine room, but not necessarily true in the deck. We control for the following voyage and vessel characteristics: crew size, whether embarking from home country, whether discharging at home country, gross tonnage of ship, year ship was constructed and intended duration of the voyage. When the "firm-level" controls are added, the steam premium actually increases for the ablebodied seamen and carpenters. In retrospect this is not surprising. There is a premium for longer voyages, most plausibly a compensating differential, and steam voyages were on average shorter than sail voyages. In contrast, the addition of the "firm-level" controls reduces the estimated steam premium for mates. The regression results suggest that part of the premium for mates in steam vessels was from having responsibility over a larger cargo (as measured by gross tonnage of the vessel). While at sea, the mates have to ensure the security of the cargo. When the vessel stops at a port, the mate must stay behind at the vessel to watch the cargo; the rest of the crew can go pursue the diversions on the land. In our sample, the steam vessels have much higher gross tonnage than sail vessels, and since mates are paid more when gross tonnage is higher (the coefficient for gross tonnage is positive and significant), when we omit gross tonnage from the regression we get a higher steam premium.

In the final column of Table 5, we control simultaneously for literacy, country of birth and voyage characteristics. For bosuns, cooks and ordinary seamen, there is no residual steam premium. The point estimate of the residual steam premium for mates is now small and 
insignificant. The premium of 12 percent originally observed for mates (column 1) can be explained by a combination of a skill premium proxied by national origin, as well as compensation for working with larger cargos. The latter compensation may represent a combination of a skill premium, a compensating differential and an efficiency wage.

In contrast, significant unexplained steam premia remain for able-bodied seamen and for carpenters. For able-bodied seamen, we are particularly confident that for the steam is not related to compensating differentials. This is not only because controlling for voyage characteristics failed to eliminate the steam premium (on the contrary, the steam premium increased). This is also because of the absence of a premium for ordinary seamen. Ordinary seamen and ablebodied seamen worked and lived side by side, and differed only in their experience and skill. Since there is no steam premium for ordinary seamen, it would be hard to maintain that changes in the work environment underlie the skill premium for able-bodied seamen. The most plausible explanation for the steam premium for able-bodied seamen is that it reflects a reward for unmeasured quality of the worker. Since fewer seamen are hired, each able-bodied seaman had to be capable of performing a larger set of tasks. In a normal voyage by a steam vessel, the skills of the able-bodied seaman might only marginally affect the success of the voyage. However, in a voyage where the steam engine broke down or the coal supply got depleted, the steam vessel would have to revert to sail technology, and the skills of the able-bodied seamen would be pivotal. It is difficult to handle the whole ship's sails with only a few co-workers. Less specialization is possible, and any single worker has to have both knowledge and physical ability. Additionally, it takes some flexibility to adapt the rigging skills learned in a sail vessel to steam vessel, as the latter sometimes used different sail plans. In other words, among the able-bodied seamen, demand for narrowly-defined, job-specific skills may have been usurped by a demand for general ability. Meyer (2002) reaches this conclusion for U.S. industry in the latter half of the nineteenth century. 
For carpenters, we can only conjecture about their sizable steam premium. Despite their name, carpenters were expected to be able to work with both wood and iron, the latter being a more demanding skill. ${ }^{21}$ Perhaps on steam vessels the ratio of iron to wood work was higher, demanding more skilled carpenters.

\section{Panel estimates of the steam premium}

In this subsection we try a different approach to understand the steam premium. Our data allow us to create a limited panel, matching observations with the same surname, first name, birth year, country and city of birth. ${ }^{22}$ The process allows us to identify a substantial panel consisting of 21,948 observations and 9,263 individuals with two or more observations. Unfortunately there are few individuals who actually switch technologies between sail and steam. $^{23}$ We observe only 24 of them, accounting for 69 observations. In Table 6, we report estimates from wage equations which include individual fixed effects. Not surprisingly, given the small number of switchers, the coefficient on steam is still positive $(0.141$ in the specification which includes voyage characteristics) but no longer significant.

In Table 7, we investigate further the extent to which the wage premium on steam vessels is due to unobserved quality differences, particularly among able-bodied seamen and carpenters. We found in Table 5 that the steam premium persisted for these occupations even when a variety of voyage, year and individuals controls were added to the regression. We estimated wage equations on sail vessels, controlling for year and the full set of individual and voyage characteristics. In the table we report the average percentile position in the residual distribution

\footnotetext{
${ }^{21}$ Meyer (2002, Figure 2a) compares the daily wages of U.S. wood workers to metal workers from 1855 to 1880. Until 1870, the two groups had similar wages. Afterwards, metal workers received higher wages.

${ }^{22}$ To increase sample sizes, we include all years 1861-1922 in this exercise. We start with 168,177 observations which are from 155,492 distinct individuals.

${ }^{23}$ Chari and Hopenhayn (1991), whose model has been found consistent with the data used here (Thompson, 2003), predict that no one switches technologies.
} 
of those individuals who switched technologies. We find no evidence of higher unobserved quality among mates. On average, they were at the $46^{\text {th }}$ percentile of the residual distribution in sail. Able-bodied seamen who switched to steam were at the $56^{\text {th }}$ percentile of the residual distribution in sail, but we again have very few observations. Similar to the findings related to industry wage premia (Krueger and Summers, 1988; Murphy and Topel, 1990), the preceding suggests that the steam premium may reflect a combination of workplace and worker characteristics. The caveat, of course, is that we have only a handful of observations so the evidence presented here is suggestive rather than conclusive.

\section{Conclusions}

Not much is known about the evolution of the wage structure at the end of the nineteenth century and beginning of the twentieth century because individual-level wage data that are collected consistently over time are not available until the second half of the twentieth century. Yet, this is a critical juncture in our economic history. Many of today's modern economies began industrialization then; the modern wage structure has its roots at the turn of the century. We have taken advantage of a data set on merchant mariners to detail the skill premium during this period, and to estimate the impact of technical change on the wage structure.

Using wage observations from voyages on sail vessels during the period 1865-1905, we found that the skill premium, as measured by the ratio of skilled (mates') to less skilled (ablebodied seamen's) wages or as the ratio of the $90^{\text {th }}$ to $10^{\text {th }}$ percentile wages among mariners, did not undergo dramatic changes. Skilled labor earned roughly twice as much as less skilled labor, which is similar to the skilled/unskilled wage ratios measured by several different studies for the pre-1940 part of the twentieth century. Thus, in the eighty years preceding 1940, there appears to have been no major compression or dispersion. We do find, however, evidence of steam's impact. Wages of sail makers, an occupation that was made obsolete by the diffusion of steam, 
steadily declined over this period. Wages of able-bodied seamen, who were employed in smaller number on steam, also fell while wages in occupations such as cooks and stewards where skills were portable across technologies remained unaffected.

We next examined the period when both sail and steam vessels provided transoceanic shipping services, 1891-1912. Although the total crew size was similar between the two technologies, the occupational composition and wages had important differences. Wage level and wage inequality were higher on steam vessels, and this is mostly driven by the creation of the new occupation, engineer. On this evidence alone, we could conclude that the switch from sail to steam was skill-biased. This would clearly gloss over the true complexities of the process of technical change. On the one hand, the switch from sail to steam had some elements that were skill-replacing. Steam vessels destroyed the sail maker occupation, an artisan occupation. Also, production work was deskilled in steam: able-bodied seamen (essentially, artisans) were replaced by less skilled workers (trimmers, who moved coal from place to place, and firemen, who shoveled coal into furnaces). On the other hand, there is evidence of skill-biased technological change even beyond the creation of the engineer occupation. Able-bodied seamen receive a twenty percentage point premium in steam for what we believe is general ability; a steam crew has less than half the number of able-bodied seamen as a sail crew, and likely each able-bodied seaman aboard a steam vessel had to be capable of performing a wider set of tasks. Also, carpenters receive a similarly large steam premium, likely for skill in metal work. Finally, mates receive a six percentage point premium in steam that is related to national origin, which we believe is a proxy for worker quality (e.g., rigor of training and exposure to steam technology).

The steam engine was applied to many other industries, and the empirical findings here should have relevance for these other industries. A few caveats are in order, however. First, the industry we have considered crosses country borders: the crew came from all over the world. If 
we were interested in the impact of steam on a particular country's wage structure, we would need to see what type of worker that country tends to supply. Britain, which supplied a disproportionate share of the engineers and mates in steam vessels, gained more skilled jobs than any other country, and so technical change might appear more skill-biased for Britain than other countries. Second, land-based firms could have gotten away with hiring fewer engineers, since they can pay for an engineer when a machinery problem arises. Ships have to staff in anticipation of their problems; once at sea, they will be unable to get additional help. This might mean that the number of new skilled jobs might be fewer than predicted from the example of the merchant shipping industry. Finally, part of the steam premium that we observed could have been temporary, owing to the shortage of qualified engineers.

Our findings might also have implications for the contemporary debate over the cause of rising wage inequality since the 1970 s. Wage inequality is higher on steam vessels than sail vessels, and as a steam technology spreads while sail technology is phased out, wage inequality will rise (all else constant). In sail vessels, the 90/10 ratio averaged 2.1, in steam vessels, 2.9. There is a $40 \%$ increase in the $90 / 10$ ratio switching completely from the old technology to the new one. This is similar to the wage inequality increase between the early 1970 s and late 1980s (e.g., Katz and Murphy, 1992; Juhn, Murphy and Pierce, 1993; Katz and Autor, 1999). Moreover, the modern rise in wage inequality appears to be due both to an increase in wages for new types of formal skills, as well as to increased demand for general ability. The experience with steam during the second industrial revolution turns out to have much in common with the computer revolution. 


\section{References}

Acemoglu, Daron, "Why Do New Technologies Complement Skills? Directed Technical Change and Wage Inequality,” Quarterly Journal of Economics 113 (1998): 1055-1089.

Acemoglu, Daron, "Technical Change, Inequality and the Labor Market," Journal of Economic Literature 40 (2002): 7-72.

Atack, Jeremy, Fred Bateman, and Robert Margo, "Rising Wage Dispersion Across American Manufacturing Establishments, 1850-1880,” NBER Working Paper No. 7932 (2000).

Autor, David, Alan Krueger, and Lawrence Katz, "Computing Inequality: Have Computers Changed the Labor Market?” Quarterly Journal of Economics 113 (1998): 1169-1213.

Berman, Eli, John Bound, and Zvi Griliches, "Changes in the Demand for Skilled Labor within U.S. Manufacturing Industries: Evidence from the Annual Survey of Manufactures," Quarterly Journal of Economics 109 (1994): 367-397.

Braverman, Harry, Labor and Monopoly Capital: The Degradation of Work in the Twentieth Century, New York: Monthly Review Press (1974).

Burton, Valerie, "The Making of a Nineteenth Century Profession: Shipmasters and the British Shipping Industry," Journal of the Canadian Historical Association 1 (1990): 97-118.

Caselli, Francesco, "Technological Revolutions," American Economic Review 89 (1999): 78102.

Chari, V.V., and Hugo Hopenhayn, "Vintage Human Capital, Growth, and the Diffusion of New Technology," Journal of Political Economy, 99 (1991): 1142-1165.

Crafts, Nicholas, "Steam as a General Purpose Technology: A Growth Accounting Perspective," Economic Journal 114 (2004): 338-351.

Doms, Mark, Timothy Dunne, and Kenneth Troske, "Workers, Wages, and Technology," Quarterly Journal of Economics 112 (1997): 253-290.

Galor, Oded, and Omer Moav, "Ability Biased Technological Transition, Wage Inequality and Economic Growth,” Quarterly Journal of Economics 115 (2000): 469-498.

Gardiner, Robert, and Basil Greenhill (eds.), The Advent of Steam: The Merchant Steamship Before 1900, London: Conway Maritime Press (1993).

Goldin, Claudia, and Lawrence F. Katz, "The Origins of Technology-Skill Complementarity," Quarterly Journal of Economics 113 (1998): 693-732.

Goldin, Claudia, and Lawrence F. Katz, "The Returns to Skill in the United States Across the Twentieth Century,” NBER Working Paper No. 7126 (1999).

Goldin, Claudia, and Robert A. Margo, "The Great Compression: The Wage Structure in the 
United States in Mid-Century," Quarterly Journal of Economics 107 (1992): 1-34.

Greenwood, Jeremy, and Mehmet Yorukoglu, "1974," Carnegie-Rochester Conference Series on Public Policy 46 (1997): 49-95.

Griffiths, Denis, Steam at Sea, London: Conway Maritime Press (1997).

Griliches, Zvi, "Capital-Skill Complementarity," Review of Economics and Statistics 51 (1969): 465-468.

Hounshell, David, From the American System to Mass Production, Baltimore: Johns Hopkins Press (1984).

James, John A., and Jonathan S. Skinner, "The Resolution of the Labor-Scarcity Paradox," Journal of Economic History 45 (1985): 513-550.

Jovanovic, Boyan, "Vintage Capital and Inequality, Review of Economics and Dynamics, 1 (1998) 497-530.

Juhn, Chinhui, Kevin M. Murphy and Brooks Pierce, "Wage Inequality and the Rise in the Returns to Skill,” Journal of Political Economy 101 (1993): 410-442.

Katz, Lawrence F., and Kevin M. Murphy, "Changes in Relative Wages, 1963-1987," Quarterly Journal of Economics 107 (1992): 35-78.

Katz, Lawrence F. and David H. Autor, "Changes in the Wage Structure and Earnings Inequality," in O. Ashenfelter and D. Card (eds.), Handbook of Labor Economics, Amsterdam: Elsevier Science Publishing (1999).

Kemp, Peter, Oxford Companion to Ships and Sea, Oxford: Oxford University Press (1976).

Krueger, Alan, and Lawrence Summers, "Efficiency Wages and the Inter-Industry Wage Structure," Econometrica 56 (1988): 259-293.

Lindert, Peter, and Jeffrey Williamson, American Inequality: A Macroeconomic History, New York: Academic Press (1980).

Lindert, Peter, and Jeffrey Williamson, "English Workers' Living Standards during the Industrial Revolution: A New Look," The Economic History Review 36 (1983): 1-25.

Maritime History Archive, Ships and Seafarers of Atlantic Canada, CD-ROM, St. John's: Memorial University of Newfoundland (1998).

McCusker, John J., "Comparing the Purchasing Power of Money in Great Britain from 1264 to 2002," Economic History Services (2003). URL: http://www.eh.net/hmit/ppowerbp/.

Marglin, Stephen, "What Do Bosses Do? The Origins and Functions of Hierarchy in Capitalist Production," Review of Radical Political Economics 3 (1974): 33-60. 
Meyer, Peter, "Technological Uncertainty and Earnings Dispersion in U.S. Iron Work, 18651880," BLS Working Paper (2002).

Mokyr, Joel, The Levers of Riches: Technological Creativity and Economic Progress, New York: Oxford University Press (1990).

Murphy, Kevin M., and Robert Topel, "Efficiency Wages Reconsidered: Theory and Evidence," in Yoram Weiss and Gideon Fishelson (eds.), Advances in the Theory and Measurement of Unemployment, London: Macmillan (1990).

Nelson, Richard, and Richard Phelps, "Investment in Humans: Technological Diffusion and Economic Growth," American Economics Association Papers and Proceedings 56 (1966): $69-75$.

Officer, Lawrence H., "Exchange Rate between the United States Dollar and the British Pound, 1791-2000," Economic History Services (2001). URL: http://www.eh.net/hmit/ exchangerates/pound.php.

Rogers, Everett, Diffusion of Innovation, New York: The Free Press (1995).

Rosenberg, Nathan and Manuel Trajtenberg, "A General Purpose Technology at Work: The Corliss Steam Engine in the Late $19^{\text {th }}$ Century US," NBER Working Paper No. 8485 (2001).

Rubenstein, Yonna, and Daniel Tsiddon, "Coping with Technological Progress: The Role of Ability in Making Inequality So Persistent," Tel Aviv University Working Paper (1999).

Sager, Eric W., Seafaring Labour, Montreal: McGill-Queen’s University Press (1989).

Sager, Eric W., Ships and Memories, Vancouver: University of British Columbia Press (1993).

Sager, Eric W., and Gerald E. Panting, Maritime Capital, Montreal: McGill-Queen's University Press (1990).

Smith, H.G., and L.C. Brown, "Shipyard statistics," in F.G. Fasset (ed.) The Shipbuilding Business in the United States of America, New York: The Society of Naval Architects and Marine Engineers (1948), Volume 1, pp. 61-200.

Thompson, Peter, "Technological Change and the Age-Earnings Profile: Evidence from the International Merchant Marine, 1861-1912," Review of Economic Dynamics 6 (2003): 578601.

Tyler, David Budlong, Steam Conquers the Atlantic, New York: Arno Press (1972). (Reprint of 1939 book published by D. Appleton-Century.)

Williamson, Jeffrey G., "Earnings Inequality in Nineteenth-Century Britain," Journal of Economic History 40 (1980): 457-475. 
TABLE 1. Comparison of in-sample and not-in-sample vessels

\begin{tabular}{|c|c|c|c|c|c|c|}
\hline & \multicolumn{2}{|c|}{ ALL OCEAN-GOING VESSELS } & \multicolumn{2}{|c|}{ SAIL } & \multicolumn{2}{|c|}{ STEAM } \\
\hline & In sample & Not in sample & In sample & Not in sample & In sample & Not in sample \\
\hline \multicolumn{7}{|l|}{ Type of vessel } \\
\hline Steam-powered & 16 & 148 & 0 & 0 & 16 & 148 \\
\hline Barque & 72 & 125 & 72 & 125 & 0 & 0 \\
\hline Barquentine & 7 & 68 & 7 & 68 & 0 & 0 \\
\hline Brig & 2 & 8 & 2 & 8 & 0 & 0 \\
\hline Ship & 64 & 77 & 64 & 77 & 0 & 0 \\
\hline Total Number & 161 & 426 & 145 & 278 & 16 & 148 \\
\hline Gross tonnage & 1,354 & 688 & 1,185 & 1,354 & 2,884 & 253 \\
\hline Length & 202 & 147 & 189 & 171 & 315 & 99 \\
\hline Width & 38 & 30 & 37 & 35 & 44 & 20 \\
\hline Depth & 22 & 16 & 22 & 19 & 23 & 9 \\
\hline Year constructed & 1879 & 1884 & 1878 & 1879 & 1894 & 1895 \\
\hline Year registered & 1881 & 1887 & 1879 & 1881 & 1905 & 1900 \\
\hline Year abandoned & 1898 & 1905 & 1897 & 1899 & 1911 & 1917 \\
\hline
\end{tabular}

Data from vessel registry database. Ocean-going vessels with active registration any time from 1891-1912 at one of the four ports with crew data (namely, Halifax, St. John, Windsor and Yarmouth) are used in above analysis. "In sample" means that individual-level crew information is available for this vessel. 
TABLE 2. Comparison of in-sample and not-in-sample voyages

\begin{tabular}{|c|c|c|c|c|c|c|}
\hline & \multicolumn{2}{|c|}{ ALL OCEAN-GOING VESSELS } & \multicolumn{2}{|c|}{ SAIL } & \multicolumn{2}{|c|}{ STEAM } \\
\hline & In sample & Not in sample & In sample & Not in sample & In sample & Not in sample \\
\hline \multicolumn{7}{|l|}{ Type of vessel } \\
\hline Steam-powered & 115 & 8 & 0 & 0 & 115 & 8 \\
\hline Barque & 201 & 327 & 201 & 327 & 0 & 0 \\
\hline Barquentine & 7 & 61 & 7 & 61 & 0 & 0 \\
\hline Brig & 0 & 0 & 0 & 0 & 0 & 0 \\
\hline Ship & 241 & 237 & 6241 & 237 & 0 & 0 \\
\hline Total Number & 564 & 633 & 449 & 625 & 115 & 8 \\
\hline Gross tonnage & 1,708 & 1,148 & 1,406 & 1,141 & 2,887 & 1,728 \\
\hline Length & 229 & 189 & 206 & 187 & 317 & 276 \\
\hline Width & 40 & 21 & 39 & 37 & 44 & 35 \\
\hline Depth & 23 & 16 & 23 & 21 & 24 & 23 \\
\hline Year constructed & 1885 & 1880 & 1882 & 1880 & 1896 & 1884 \\
\hline Year registered & 1886 & 1881 & 1882 & 1881 & 1903 & 1891 \\
\hline Year abandoned & 1903 & 1900 & 1901 & 1901 & 1910 & 1898 \\
\hline Year voyage commenced & 1897 & 1894 & 1895 & 1894 & 1905 & 1892 \\
\hline $\begin{array}{l}\text { Intended duration of } \\
\text { voyage (months) }\end{array}$ & 24 & 24 & 25 & 24 & 21 & 12 \\
\hline \multicolumn{7}{|l|}{ Intended destination } \\
\hline Argentina & $6.5 \%$ & $6.3 \%$ & $5.0 \%$ & $6.4 \%$ & $12.6 \%$ & $0.0 \%$ \\
\hline Brazil & $14.8 \%$ & $14.3 \%$ & $15.6 \%$ & $14.5 \%$ & $11.7 \%$ & $0.0 \%$ \\
\hline Canada & $25.6 \%$ & $27.4 \%$ & $24.6 \%$ & $26.6 \%$ & $29.7 \%$ & $100.0 \%$ \\
\hline Great Britain & $9.6 \%$ & $10.2 \%$ & $10.2 \%$ & $16.0 \%$ & $7.2 \%$ & $0.0 \%$ \\
\hline USA & $23.8 \%$ & $26.0 \%$ & $26.0 \%$ & $17.4 \%$ & $15.3 \%$ & $0.0 \%$ \\
\hline Other & $19.7 \%$ & $18.7 \%$ & $18.7 \%$ & $19.2 \%$ & $23.4 \%$ & $0.0 \%$ \\
\hline
\end{tabular}

Ocean-going vessels with active registration anytime from 1891-1912 at one of the four ports with crew data (namely, Halifax, St. John, Windsor and Yarmouth) are used in above analysis. "In sample" means that individual-level crew information is available for this vessel. 
TABLE 3. Employment by occupation: steam vs. sail

\begin{tabular}{|c|c|c|c|c|}
\hline \multirow{2}{*}{ OCCUPATION } & \multicolumn{2}{|c|}{ SAIL } & \multicolumn{2}{|c|}{ STEAM } \\
\hline & Number & $\%$ of Crew & Number & $\%$ of Crew \\
\hline 1-mate & 2.0 & $6.9 \%$ & 2.5 & $7.3 \%$ \\
\hline 2-bosun & 1.1 & $3.9 \%$ & 0.5 & $1.4 \%$ \\
\hline 3-able-bodied seamen & 22.6 & $70.0 \%$ & 9.0 & $24.4 \%$ \\
\hline 4-ordinary seamen & 2.4 & $7.0 \%$ & 0.9 & $2.9 \%$ \\
\hline 5-cook/steward & 1.6 & $5.6 \%$ & 2.5 & $7.7 \%$ \\
\hline 6-carpenter & 0.8 & $2.4 \%$ & 0.6 & $1.9 \%$ \\
\hline 7-sailmaker & 0.1 & $0.2 \%$ & 0.0 & $0.0 \%$ \\
\hline 8 -engineer & 0.0 & $0.0 \%$ & 3.9 & $12.3 \%$ \\
\hline 9-engine room occupations & 0.0 & $0.0 \%$ & 12.0 & $33.5 \%$ \\
\hline 10-other & 1.2 & $3.9 \%$ & 2.9 & $8.5 \%$ \\
\hline Total Crew & 31.8 & $100.0 \%$ & 34.7 & $100.0 \%$ \\
\hline
\end{tabular}

For voyages with years of embarkation from 1891-1912, number of workers by occupation is reported. There were 111 steam voyages and 564 sail voyages. The occupations have been aggregated as follows:

Aggregate occupation:
1-mate
2-bosun
3-able-bodied seamen
4-ordinary seamen
5-cook/steward
6-carpenter
7-engineer
8-sailmaker
9-engine room occupations

10-other
Includes:

First Mate, Second Mate, Third Mate

Bosun, Bosun/Mate

only one occupation

only one occupation

Cook, Steward, Cook/Steward

Carpenter, Carpenter/Bosun, Carpenter/AB, Carpenter's Mate, Second Mate/Carpenter Engineer, Second Engineer, Third Engineer, Fourth Engineer

Sailmaker, AB \& Sailmaker, Bosun \& Sailmaker

Leading Fireman, Fireman, Bosun \& Lamp Trimmer, Fireman \& Trimmer, Donkey Man, Trimmer (Steamer), AB \& Lamp Trimmer, AB \& Trimmer, Oiler \& Greaser

All other occupations, predominantly Boy, Stewardess, Apprentice. 
TABLE 4. Wages and wage bill share by occupation: steam vs. sail

\begin{tabular}{|c|c|c|c|c|}
\hline \multirow[b]{2}{*}{ OCCUPATION } & \multicolumn{2}{|c|}{ SAIL } & \multicolumn{2}{|c|}{ STEAM } \\
\hline & $\begin{array}{c}\text { Average wage } \\
(£ 1900) \\
\end{array}$ & $\begin{array}{c}\text { Wage bill } \\
\% \text { of Total Crew }\end{array}$ & $\begin{array}{c}\text { Average wage } \\
(£ 1900)\end{array}$ & $\begin{array}{c}\text { Wage bill } \\
\% \text { of Total Crew }\end{array}$ \\
\hline 1-mate & 7.32 & $13.9 \%$ & 9.15 & $12.2 \%$ \\
\hline 2-bosun & 5.51 & $5.6 \%$ & 5.13 & $1.2 \%$ \\
\hline 3-able-bodied seamen & 3.50 & $60.2 \%$ & 4.22 & $18.1 \%$ \\
\hline 4-ordinary seamen & 2.35 & $4.8 \%$ & 2.71 & $1.5 \%$ \\
\hline 5-cook/steward & 6.51 & $10.0 \%$ & 6.17 & $8.9 \%$ \\
\hline 6-carpenter & 5.36 & $3.5 \%$ & 5.43 & $2.0 \%$ \\
\hline 7-sailmaker & 3.86 & $0.3 \%$ & -- & $0.0 \%$ \\
\hline 8-engineer & -- & $0.0 \%$ & 10.64 & $24.3 \%$ \\
\hline 9-engine room occupations & -- & $0.0 \%$ & 4.56 & $27.9 \%$ \\
\hline 10-other & 1.48 & $1.7 \%$ & 2.43 & $3.8 \%$ \\
\hline Total Crew & 3.93 & & 5.56 & \\
\hline
\end{tabular}

See Table 3 for notes. Wages are averaged over all individuals with non-missing wages (20,160 individuals). 


\section{TABLE 5. Regression-adjusted cross-technology differences in wages by occupation for males aged 16-60}

\begin{tabular}{|c|c|c|c|c|c|c|c|c|c|}
\hline \multirow{4}{*}{\multicolumn{2}{|c|}{ OCCUPATION }} & \multicolumn{8}{|c|}{ Difference in log wage for steam, regression-adjusted for } \\
\hline & & \multirow{3}{*}{\multicolumn{2}{|c|}{$\begin{array}{l}\text { age quadratic and } \\
\text { year dummies } \\
\text { (1) }\end{array}$}} & \multicolumn{6}{|c|}{ Specification in column 1 plus: } \\
\hline & & & & \multirow{3}{*}{$\begin{array}{l}\text { literacy } \\
\begin{array}{c}(2) \\
0.1232^{* * *} \\
(0.029) \\
1,337\end{array}\end{array}$} & \multirow{2}{*}{\multicolumn{2}{|c|}{$\begin{array}{l}\text { country of birth } \\
\text { (3) }\end{array}$}} & \multirow{2}{*}{\multicolumn{2}{|c|}{$\begin{array}{c}\text { voyage } \\
\text { characteristics } \\
\text { (4) }\end{array}$}} & \multirow{2}{*}{$\begin{array}{c}\text { all previous } \\
\text { controls } \\
(5)\end{array}$} \\
\hline & & & & & & & & & \\
\hline Mate & $\begin{array}{l}\text { Log difference: } \\
\text { Standard error: } \\
\text { No. observations: }\end{array}$ & $\begin{array}{c}0.1221 \\
(0.029) \\
1,337\end{array}$ & ** & & $\begin{array}{c}0.0634 \\
(0.029) \\
1,327\end{array}$ & ** & $\begin{array}{c}0.0558 \\
(0.034) \\
1,258\end{array}$ & & $\begin{array}{l}0.0352 \\
(0.034) \\
1,249\end{array}$ \\
\hline Bosun & & $\begin{array}{c}-0.0022 \\
(0.059) \\
659\end{array}$ & & $\begin{array}{c}-0.0140 \\
(0.060) \\
659\end{array}$ & $\begin{array}{c}-0.0143 \\
(0.059) \\
651\end{array}$ & & $\begin{array}{c}-0.0522 \\
(0.071) \\
637\end{array}$ & & $\begin{array}{c}-0.0560 \\
(0.067) \\
629\end{array}$ \\
\hline \multicolumn{2}{|c|}{ Able-bodied seaman } & $\begin{array}{l}0.1674 \\
(0.026) \\
12,448\end{array}$ & *** & $\begin{array}{c}0.1677^{* * *} \\
(0.026) \\
12,448\end{array}$ & $\begin{array}{l}0.1676 \\
(0.026) \\
12,232\end{array}$ & *** & $\begin{array}{l}0.2157 \\
(0.028) \\
12,062\end{array}$ & $* * *$ & $\begin{array}{c}0.2203^{* * *} \\
(0.028) \\
11,852\end{array}$ \\
\hline \multicolumn{2}{|c|}{ Ordinary seaman } & $\begin{array}{c}-0.0781 \\
(0.109) \\
1,315\end{array}$ & & $\begin{array}{l}-0.0723 \\
(0.105) \\
1,315\end{array}$ & $\begin{array}{c}-0.0300 \\
(0.103) \\
1,281\end{array}$ & & $\begin{array}{c}-0.0151 \\
(0.100) \\
1,290\end{array}$ & & $\begin{array}{l}-0.0318 \\
(0.092) \\
1,256\end{array}$ \\
\hline \multicolumn{2}{|c|}{ Cook/ steward } & $\begin{array}{c}0.0002 \\
(0.032) \\
1,094\end{array}$ & & $\begin{array}{l}-0.0044 \\
(0.032) \\
1,094\end{array}$ & $\begin{array}{c}-0.0254 \\
(0.035) \\
1,083\end{array}$ & & $\begin{array}{c}-0.0006 \\
(0.047) \\
1,033\end{array}$ & & $\begin{array}{l}-0.0361 \\
(0.052) \\
1,024\end{array}$ \\
\hline \multicolumn{2}{|c|}{ Carpenter } & $\begin{array}{c}0.1743 \\
(0.032) \\
485\end{array}$ & $* * *$ & $\begin{array}{l}0.1690^{* * *} \\
(0.033) \\
485\end{array}$ & $\begin{array}{c}0.1585 \\
(0.039) \\
478\end{array}$ & *** & $\begin{array}{c}0.2309 \\
(0.065) \\
463\end{array}$ & $* * *$ & $\begin{array}{c}0.2190^{* * *} \\
(0.061) \\
456\end{array}$ \\
\hline
\end{tabular}

Data from 1891-1912. Each cell comes from a separate regression. Robust standard errors in parentheses. Single, double, and triple asterisks denote $90 \%, 95 \%$ and $99 \%$ level of confidence, respectively. Voyage characteristics are crew size (quadratic), whether embarking form home country, whether discharging at home country, gross tonnage, year ship was constructed, and intended duration (quadratic). 
TABLE 6. Estimation of the steam premium using panel data

\begin{tabular}{|c|c|c|c|c|c|c|}
\hline & \multicolumn{6}{|c|}{ Dependent Variable: log wage } \\
\hline & \multicolumn{2}{|l|}{ (1) } & \multicolumn{2}{|c|}{ (2) } & \multicolumn{2}{|l|}{ (3) } \\
\hline steam & $\begin{array}{c}0.1887 \\
(0.03)\end{array}$ & $* * *$ & $\begin{array}{l}0.1316 \\
(0.10)\end{array}$ & & $\begin{array}{l}0.1418 \\
(0.10)\end{array}$ & \\
\hline age & $\begin{array}{l}0.0277 \\
(0.00)\end{array}$ & $* * *$ & $\begin{array}{l}0.1167 \\
(0.10)\end{array}$ & $* * *$ & $\begin{array}{c}0.120 \\
(0.06)\end{array}$ & $* * *$ \\
\hline age squared & $\begin{array}{l}-0.0003 \\
(0.00)\end{array}$ & $* * *$ & $\begin{array}{l}-0.0015 \\
(0.00)\end{array}$ & $* * *$ & $\begin{array}{l}-0.002 \\
(0.00)\end{array}$ & $* * *$ \\
\hline year controls & yes & & yes & & yes & \\
\hline occupation dummies & yes & & no & & no & \\
\hline individual fixed effects & no & & yes & & yes & \\
\hline voyage controls & yes & & no & & yes & \\
\hline$N$ & 18,586 & & 19,726 & & 18,586 & \\
\hline
\end{tabular}

Estimates based on panel data created by matching surname, first name, birth year, country and city of birth. The panel data contains 21,948 observations and 9,263 individuals. Data from all years 1861-1922 are used. Steam effect is identified from 69 observations 24 individuals observed in both technologies. 


\section{TABLE 7. Percentile position of switchers to steam}

\begin{tabular}{lcc}
\hline OCCuPATION & $\begin{array}{c}\text { Percentile Position } \\
\text { in Wage Distribution } \\
\text { in Sail }\end{array}$ & $\begin{array}{c}\text { Number of } \\
\text { Observations }\end{array}$ \\
\hline 1-mate & 46.4 & 12 \\
2-bosun & 49.1 & 5 \\
3-able-bodied seamen & 55.8 & 9 \\
4-ordinary seamen & 38.5 & 5 \\
5-cook/steward & 52.0 & 1 \\
6-carpenter & 49.0 & 2 \\
\hline
\end{tabular}

Estimates based on panel data created by matching surname, first name, birth year, country and city of birth. The panel contains 21,948 observations and 9,263 individuals. Data from all years 18611922 are used. The table reports average percentile position of switchers in the residual wage distribution in sail. The regressions control for age, age squared, year, literacy, country of birth and voyage characteristics. 


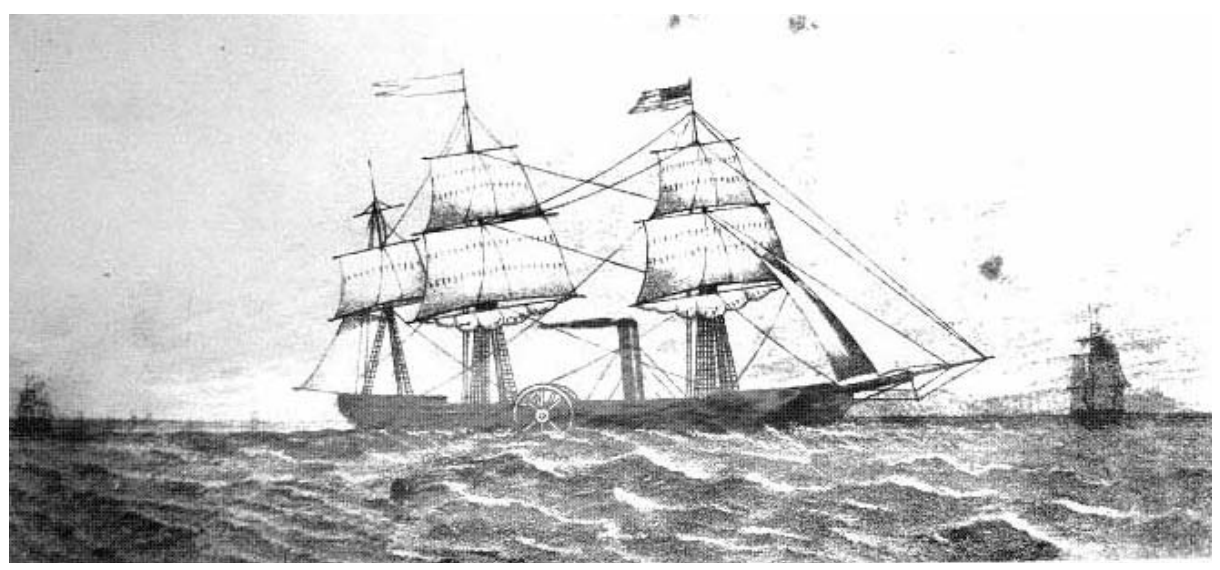

FIGURE 1. The SS Savannah. Source: Georgia Historical Society, Photographic Collection \#1361 PH, Box 29, Folder 20. 


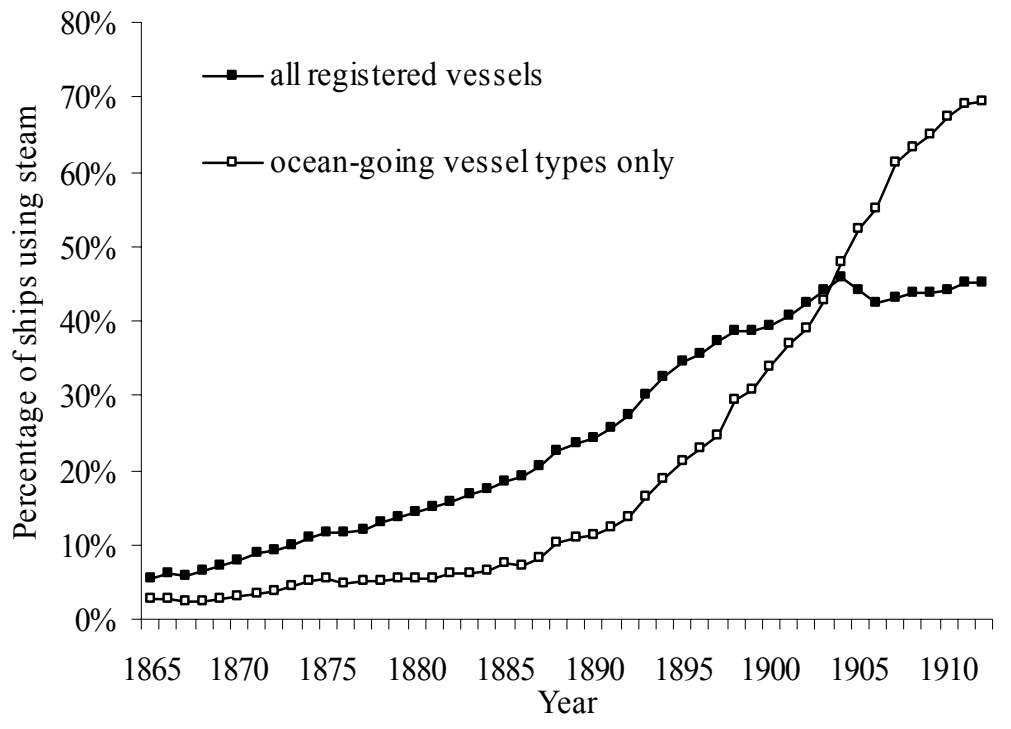

FIGURE 2. Spread of steam-powered ships in Atlantic Canada. Based on the vessel registry database, which contains data on the universe of ships registered in ten major Canadian ports. Each point gives the stock of steam-powered ships as a fraction of either the stock of all vessels or ocean-going vessels. Ocean-going vessels are defined as barquentines, barques, brigs, ships, and steam/sail. The latter type of vessel uses steam technology whereas the others use only sail technology. 


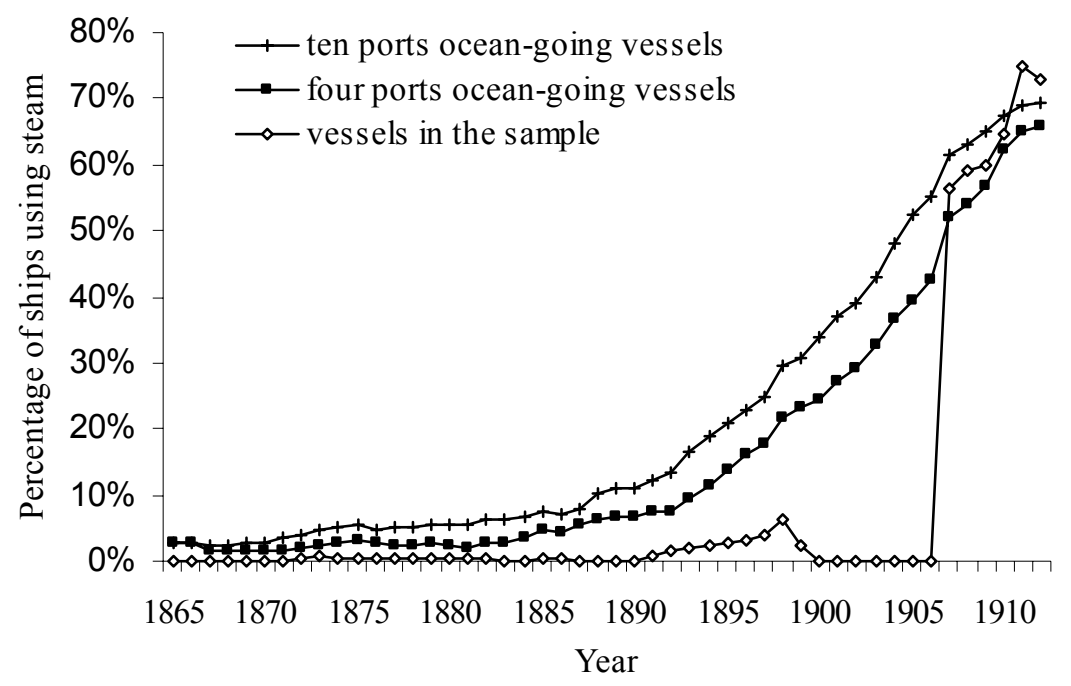

FigURE 3. Coverage of steam-powered vessels in sample. Only ocean-going vessels included in this graph. The vessel registry database contains data on the universe of ships registered in ten major Canadian ports. For ships registered in four of these ports (Halifax, St. John, Windsor and Yarmouth), data from crew agreements (on voyages, masters and ports) were collected. For a sample of ships registered in these four ports, individual-level crew information was collected. 


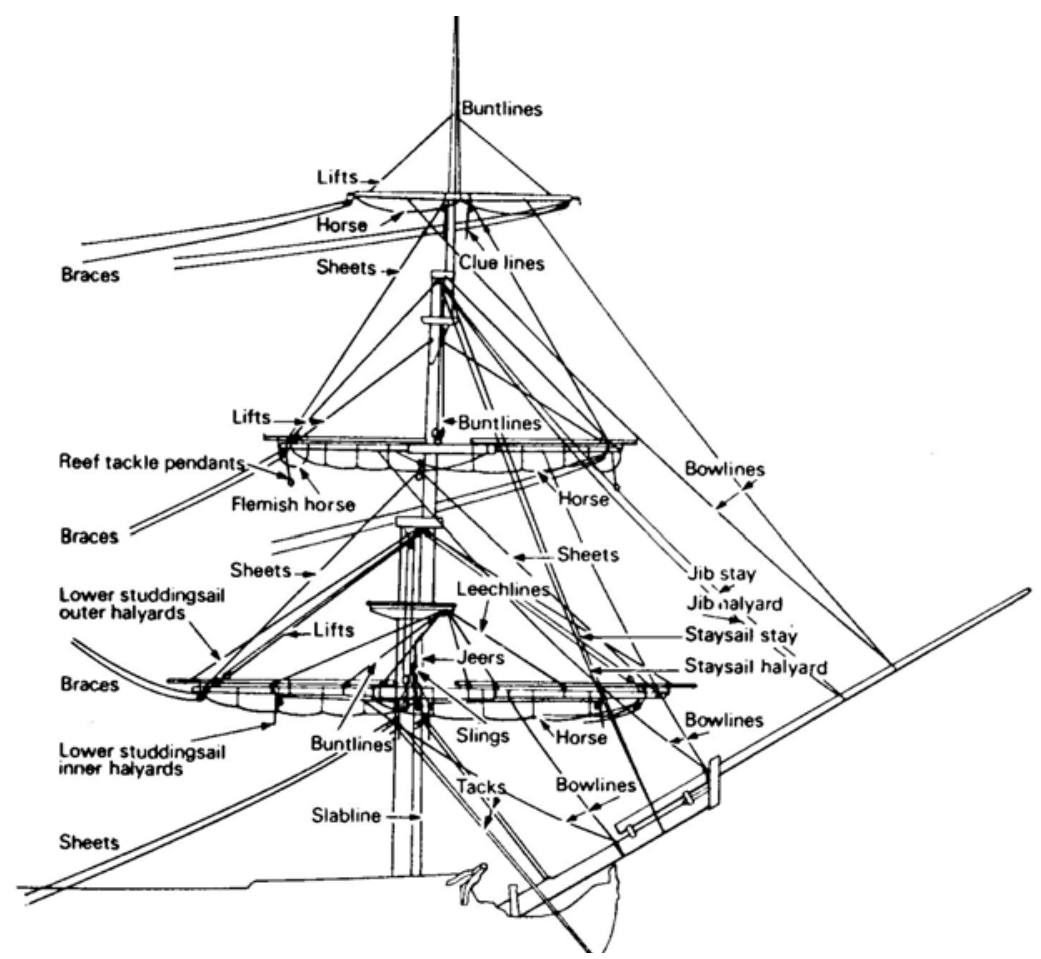

FIGURE 4. Main rigging on a ship's foremast. Source: Kemp (1976). 
Panel A. Mean Wages

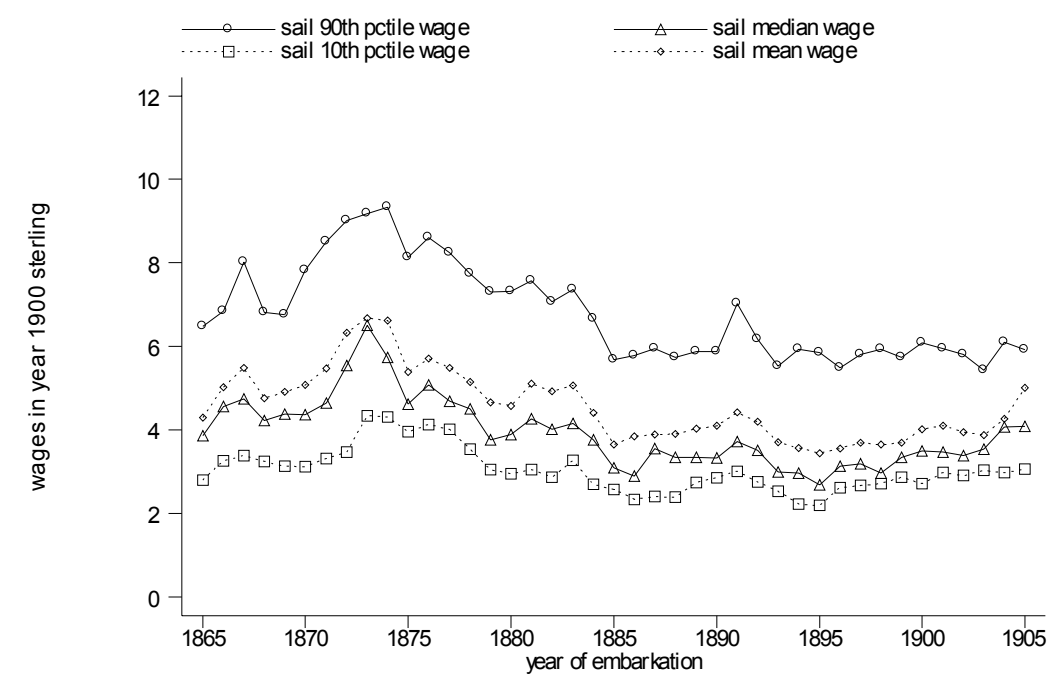

Panel B. 90th percentile wage / 10th percentile wage

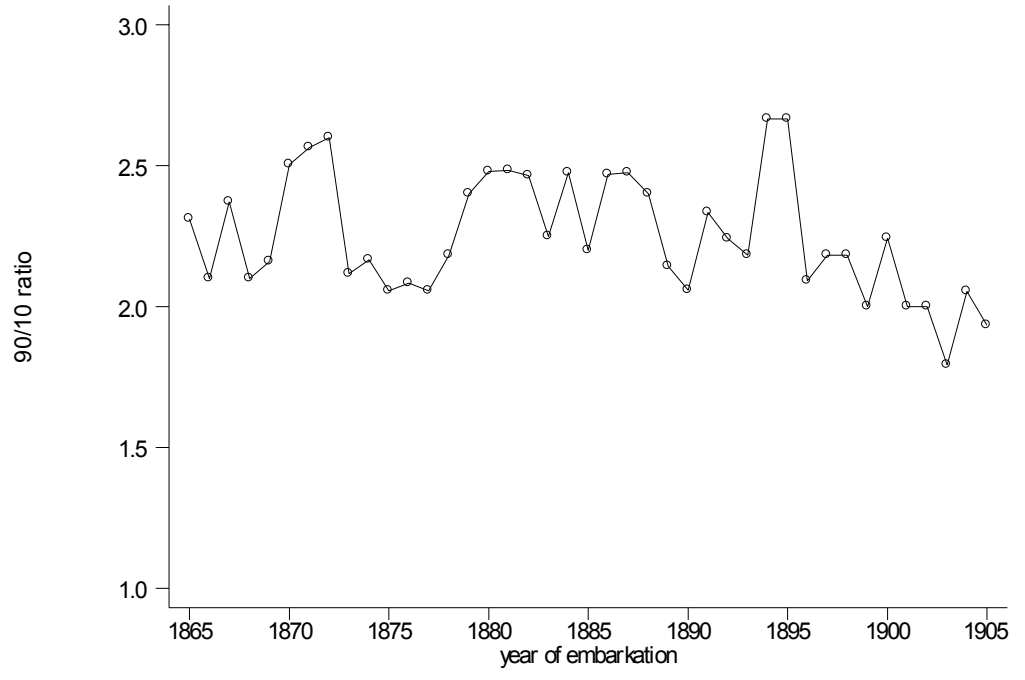

Figure 5. Wages for Male Seamen Aged 16-60 (Sail). Raw statistics computed from sample of 144,924 individuals working in sailing vessels. Year cells with fewer than 25 observations have not been graphed. 
Panel A. Mean Wages

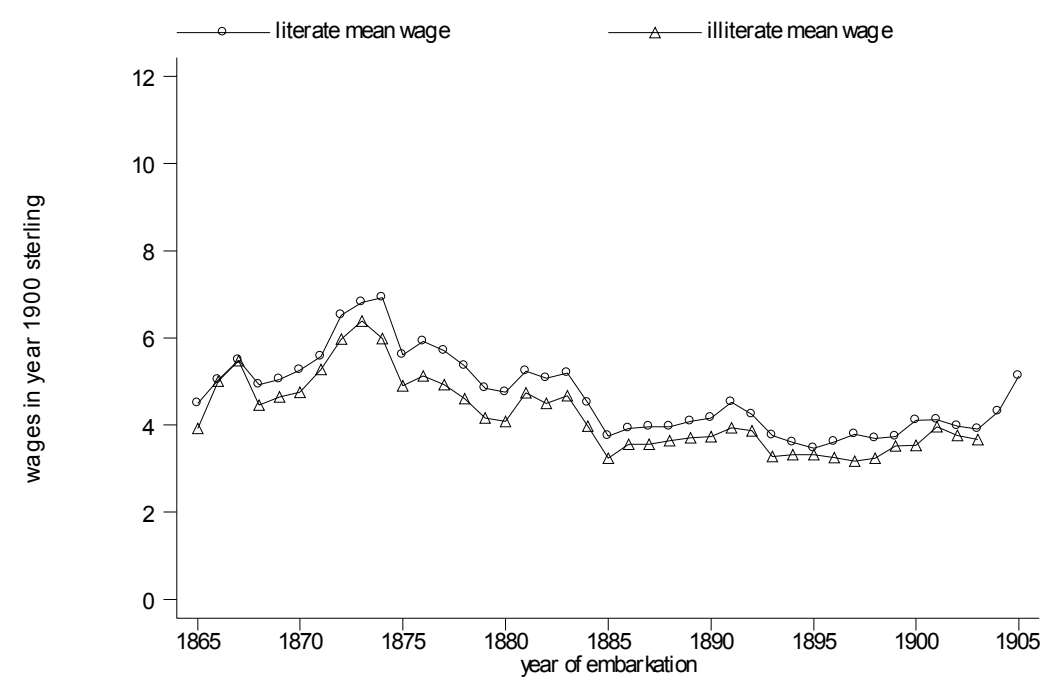

\section{Panel B. 90th percentile wage / 10th percentile wage}

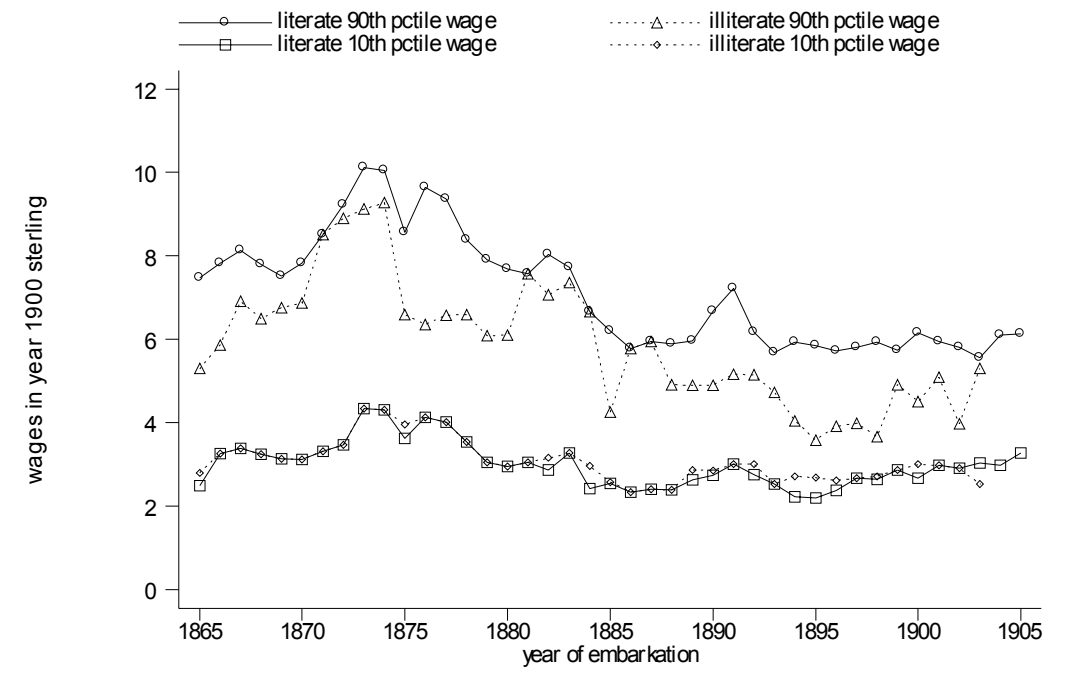

FIGURE 6. Wages by Literacy (Sail). Raw statistics. Year-literacy cells with fewer than 25 observations have not been graphed. 


\section{Panel A. Mean Wages}

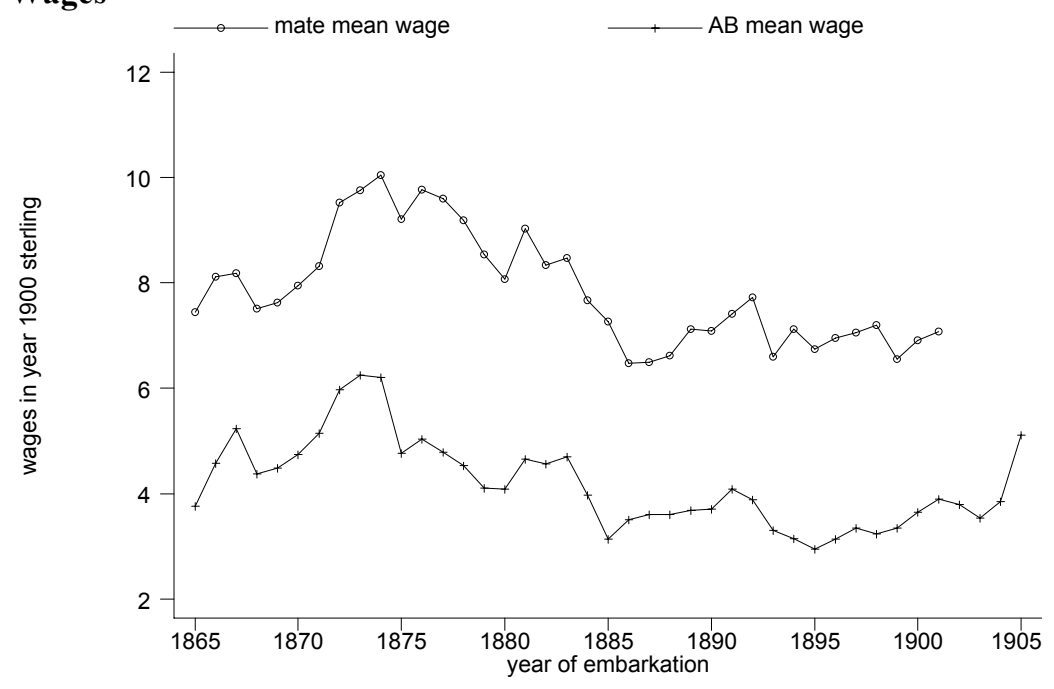

Panel B. Mate/AB Seamen Wage Ratio

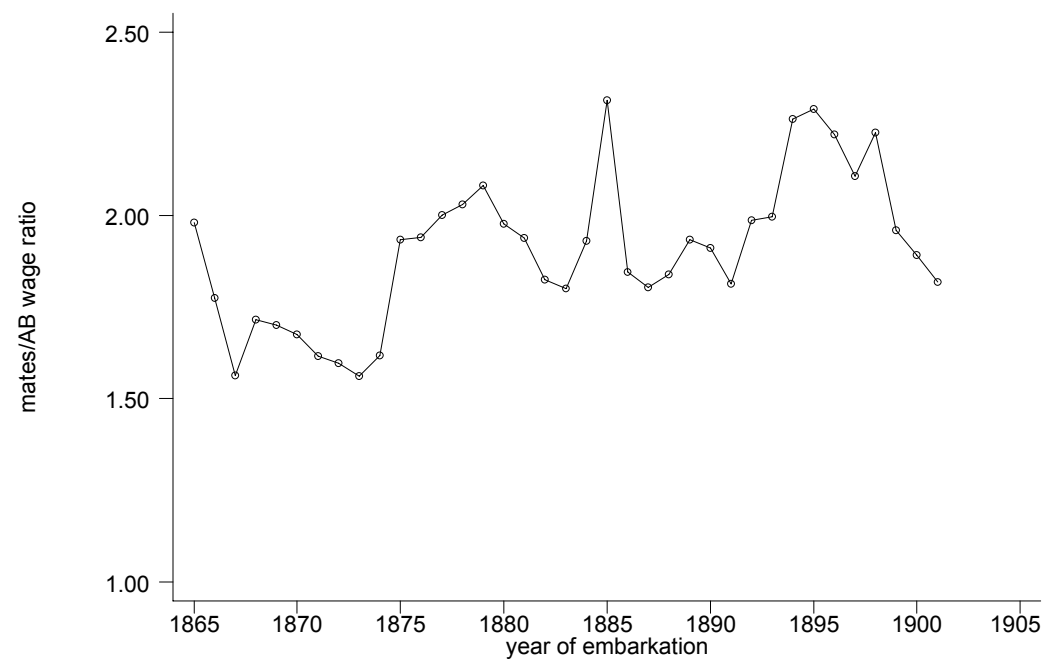

FIGURE 7. Wages by Rank (Sail). Raw statistics. Year-occupation cells with fewer than 25 observations have not been graphed. 


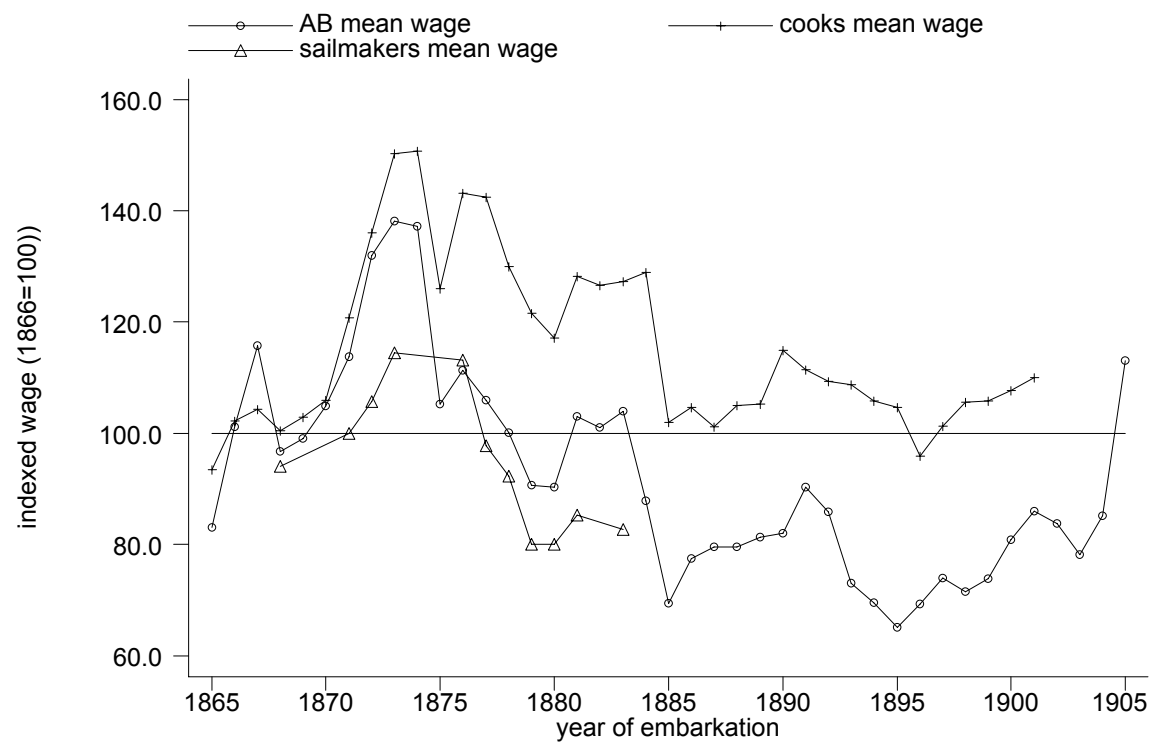

FIGURE 8. Indexed Wages in Different Occupations $(1866=100)$. Raw statistics. Year-occupation cells with fewer than 25 observations have not been graphed. 
Panel A. Comparison of Mate/AB Wage Ratio to Other Skill Premia in U.S. and Britain

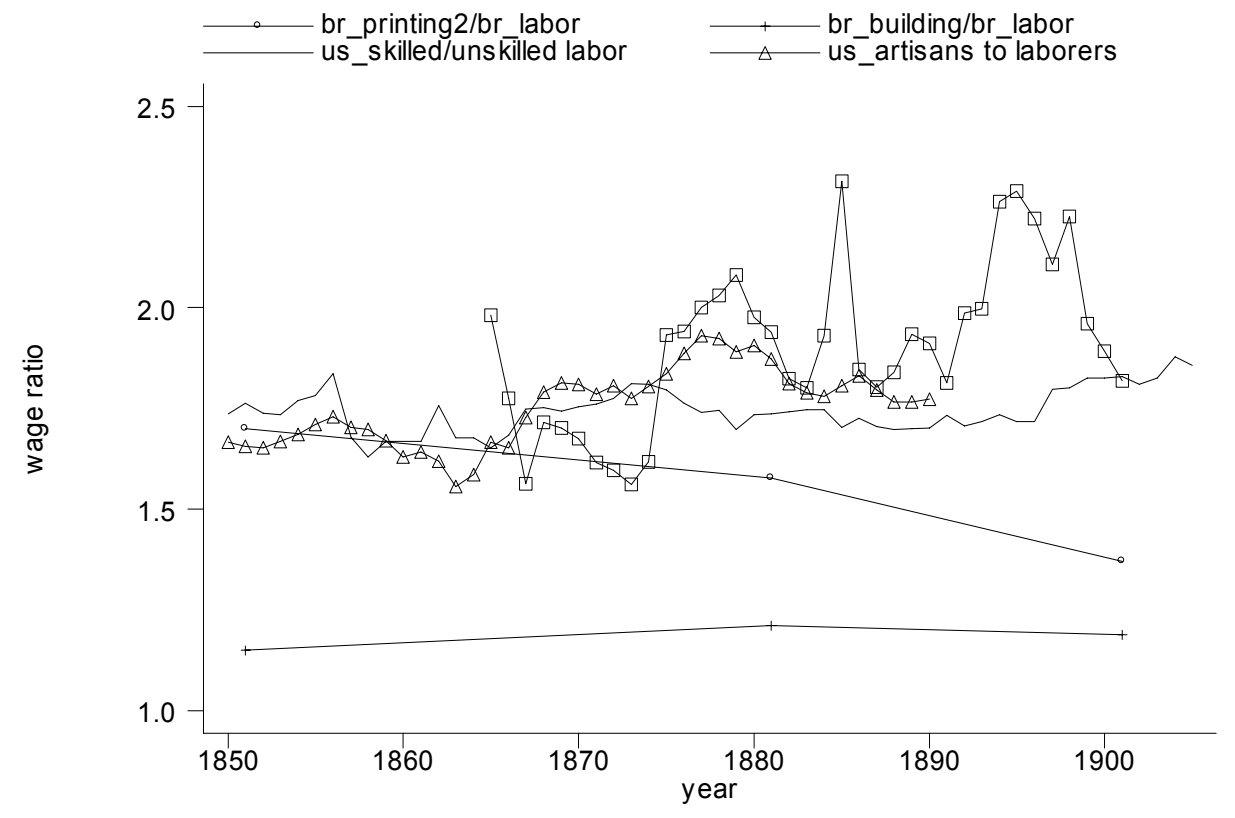

Panel B. Comparison of Mate/AB Wage Ratio to Other White-Collar/Blue-Collar Premium

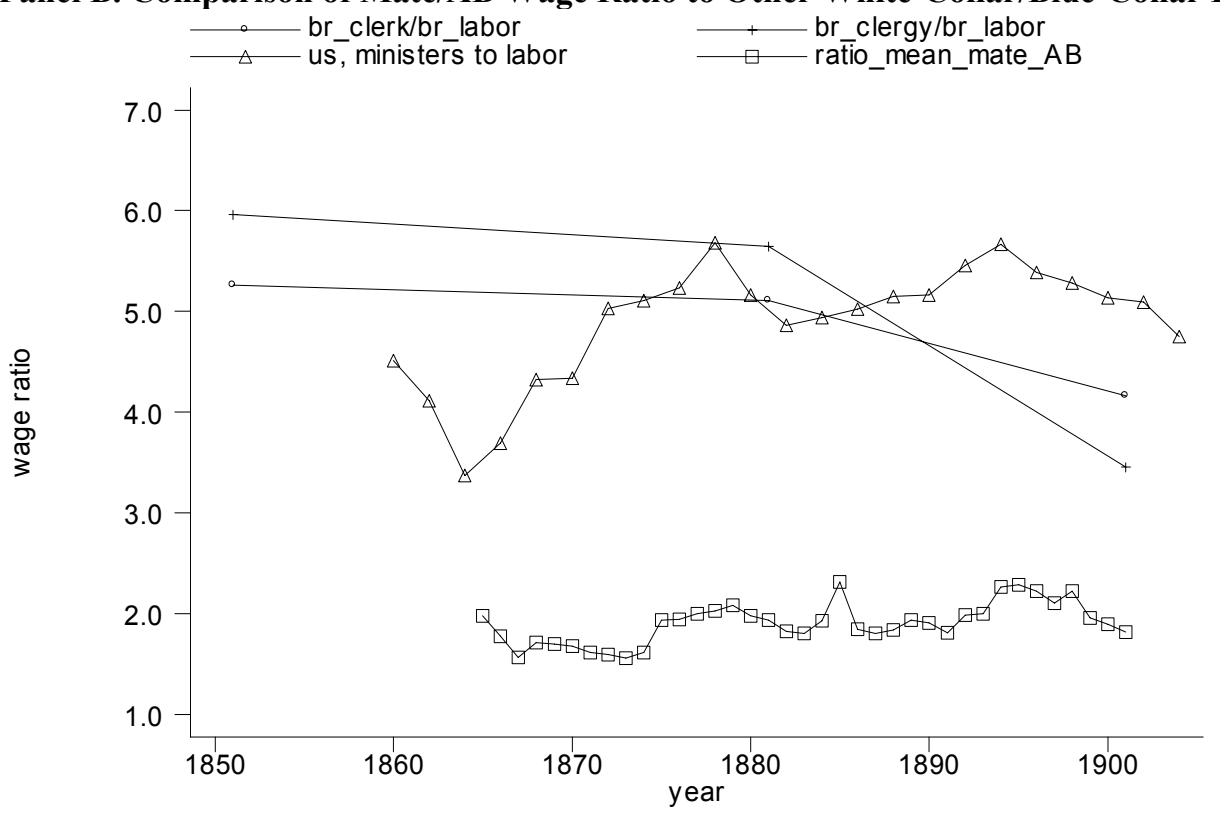

Figure 9. Comparison of Mate/AB Wage Ratio to Other Skill Premia. British data from Williamson (1980), appendix table 1. U.S. data from Lindert and Williamson (1980), appendix D. 


\section{Panel A. Mean Wages}

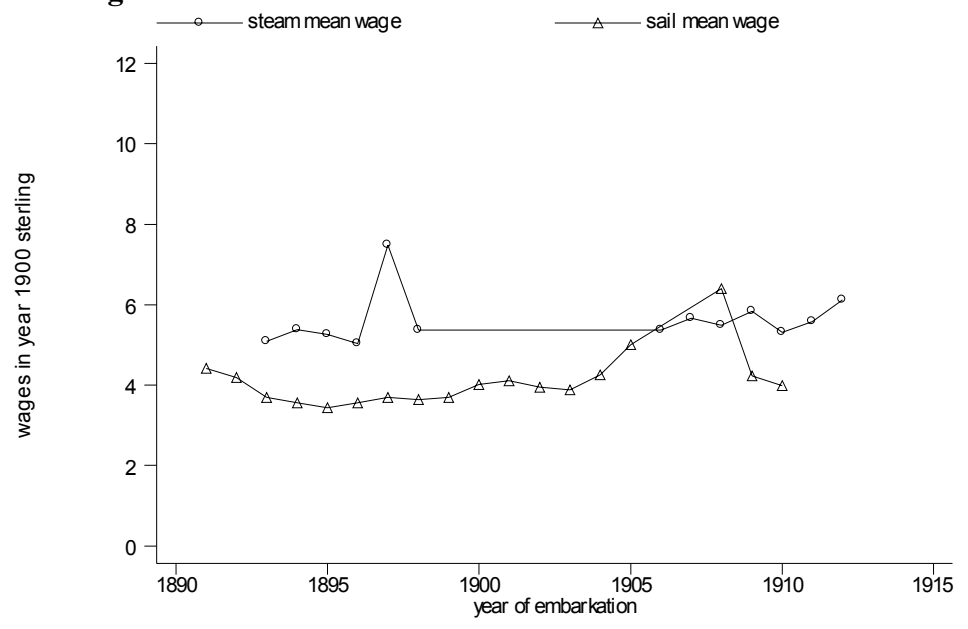

Panel B. Wages at the 10 th and 90 th percentiles

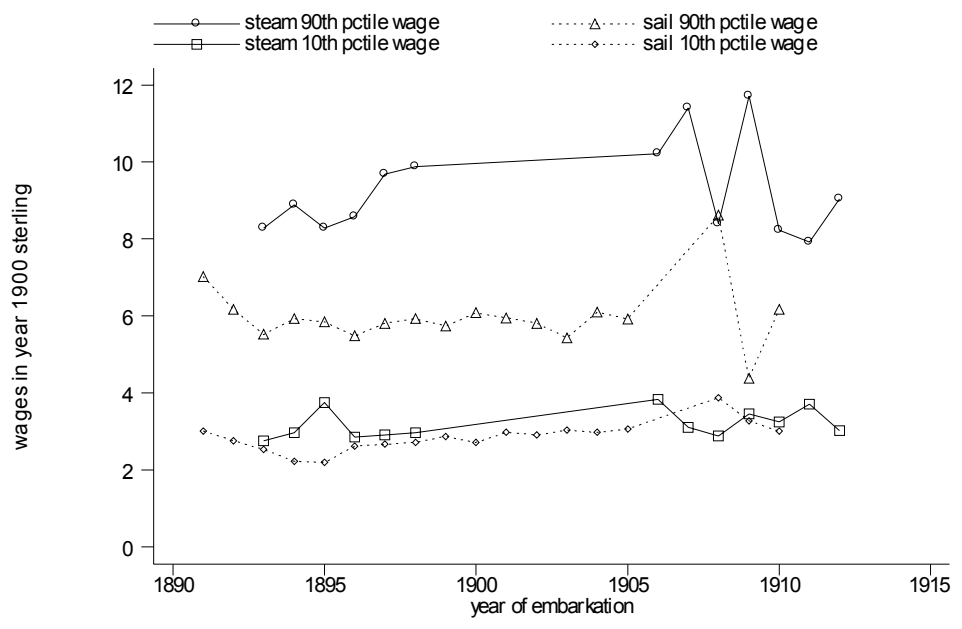

Figure 10. Wages by Technology, All Male Seamen Aged 16 to 60. Raw statistics computed from sample of 19,773 individuals (16,218 from sailing vessels and 3,555 from steam vessels. Year-technology cells with fewer than 25 observations have not been graphed. 